\title{
A gelatin/collagen/polycaprolactone scaffold for skin regeneration
}

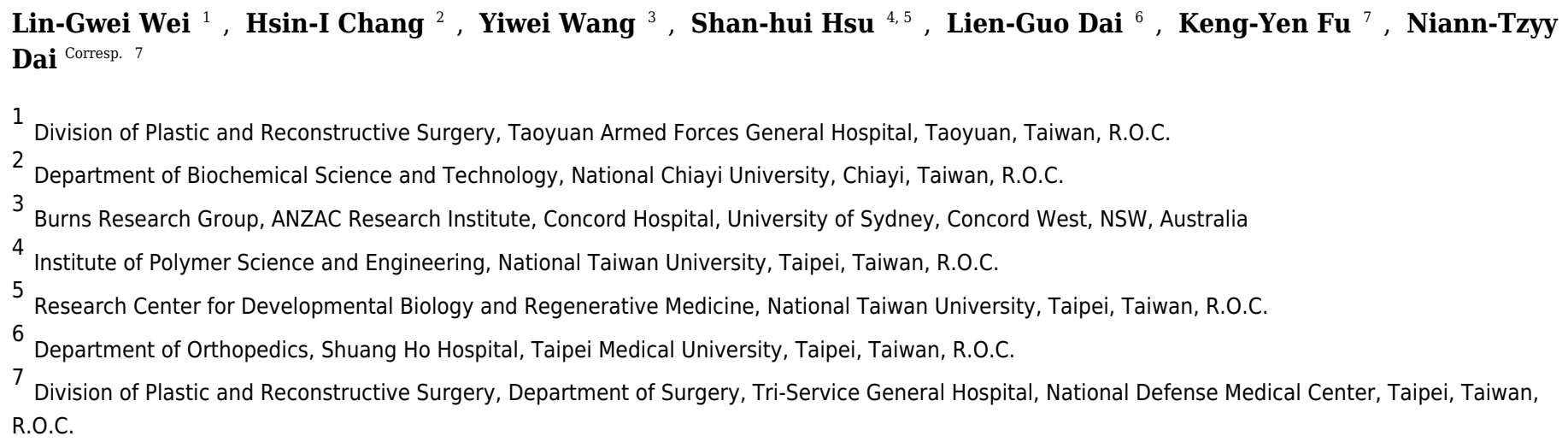

Background. A tissue-engineered skin substitute, based on gelatin (" $G$ "), collagen (" $C$ "), and poly ( $\varepsilon$ caprolactone) ( $\mathrm{PCL}$; “P”), was developed.

Method. G/C/P biocomposites were fabricated by impregnation of lyophilized gelatin/collagen (GC) mats with PCL solutions, followed by solvent evaporation. Two different GC:PCL ratios ( $1: 8$ and $1: 20)$ were used.

Results. Differential scanning calorimetry revealed that all G/C/P biocomposites had characteristic melting point of $\mathrm{PCL}$ at around $60^{\circ} \mathrm{C}$. Scanning electron microscopy showed that all biocomposites had similar fibrous structures. Good cytocompatibility was present in all G/C/P biocomposites when incubated with primary human epidermal keratinocytes (PHEK), human dermal fibroblasts (PHDF) and human adipose-derived stem cells (ASCs) in vitro. All G/C/P biocomposites exhibited similar cell growth and mechanical characteristics in comparison with C/P biocomposites. G/C/P biocomposites with a lower collagen content showed better cell proliferation than those with a higher collagen content in vitro. Due to reasonable mechanical strength and biocompatibility in vitro, G/C/P with a lower content of collagen and a higher content of $\mathrm{PCL}\left(\mathrm{GC}_{\mathrm{L}} \mathrm{P}_{\mathrm{H}}\right)$ was selected for animal wound healing studies. According to our data, a significant promotion in wound healing and skin regeneration could be observed in $\mathrm{GC}_{\mathrm{L}} \mathrm{P}_{\mathrm{H}}$ seeded with adipose-derived stem cells by Gomori's trichrome staining.

Conclusion. This study may provide an effective and low-cost wound dressings to assist skin regeneration for clinical use. 


\section{A gelatin/collagen/polycaprolactone scaffold for skin regeneration}

2 Lin-Gwei Wei ${ }^{1 \bar{\top}}$, Hsin-I Chang ${ }^{2 \bar{\top}}$, Yiwei Wang ${ }^{3}$, Shan-Hui Hsu ${ }^{4,5}$, Lien-Guo Dai ${ }^{6}$, Keng-Yen

$3 \mathrm{Fu}^{7}$, Niann-Tzyy Dai ${ }^{7, *}$

$4{ }^{1}$ Division of Plastic and Reconstructive Surgery, Taoyuan Armed Forces General Hospital,

5 Taoyuan, Taiwan, R.O.C.

6 2Department of Biochemical Science and Technology, National Chiayi University, Chiayi,

7 Taiwan, R.O.C.

8 33urns Research Group, ANZAC Research Institute, Concord Hospital, University of Sydney,

9 Concord West, NSW 2137, Australia

10 Institute of Polymer Science and Engineering, National Taiwan University, Taipei, Taiwan,

11 ROC

$12{ }^{5}$ Research Center for Developmental Biology and Regenerative Medicine, National Taiwan

13 University, Taipei, Taiwan, ROC

$14{ }^{6}$ Department of Orthopedics, Shuang Ho Hospital, Taipei Medical University, Taipei, Taiwan, 15 ROC.

$16{ }^{7}$ Division of Plastic and Reconstructive Surgery, Department of Surgery, Tri-Service General

17 Hospital, National Defense Medical Center, Taipei, Taiwan, ROC

19 T Lin-Gwei Wei, Hsin-I Chang have contributed equally to this work.

20 Corresponding author

$21 *$ Niann-Tzyy Dai

22 Division of Plastic and Reconstructive Surgery, Department of Surgery, Tri-Service General

23 Hospital, National Defense Medical Center, Taiwan, R.O.C.

24 No. 325, Section 2, Cheng-Kung Road, Nei-Hu District, Taipei 114, Taiwan, R.O.C.

25 E-mail: niantzyydai@gmail.com 


\section{ABSTRACT}

28 Background. A tissue-engineered skin substitute, based on gelatin (“G”), collagen (“C" $\mathrm{C}$ ), and poly(e-caprolactone) (PCL; “P”), was developed.

Method. G/C/P biocomposites were fabricated by impregnation of lyophilized gelatin/collagen

32 (GC) mats with PCL solutions, followed by solvent evaporation. Two different GC:PCL ratios 33 (1:8 and 1:20) were used.

34 Results. Differential scanning calorimetry revealed that all G/C/P biocomposites had characteristic melting point of $\mathrm{PCL}$ at around $60^{\circ} \mathrm{C}$. Scanning electron microscopy showed that all biocomposites had similar fibrous structures. Good cytocompatibility was present in all G/C/P biocomposites when incubated with primary human epidermal keratinocytes (PHEK), human dermal fibroblasts (PHDF) and human adipose-derived stem cells (ASCs) in vitro. All G/C/P biocomposites exhibited similar cell growth and mechanical characteristics in comparison with $\mathrm{C} / \mathrm{P}$ biocomposites. G/C/P biocomposites with a lower collagen content showed better cell proliferation than those with a 41 higher collagen content in vitro. Due to reasonable mechanical strength and biocompatibility in 42 vitro, $\mathrm{G} / \mathrm{C} / \mathrm{P}$ with a lower content of collagen and a higher content of PCL $\left(\mathrm{GC}_{\mathrm{L}} \mathrm{P}_{\mathrm{H}}\right)$ was selected 43 for animal wound healing studies. According to our data, a significant promotion in wound healing 44 and skin regeneration could be observed in $\mathrm{GC}_{\mathrm{L}} \mathrm{P}_{\mathrm{H}}$ seeded with adipose-derived stem cells by 45 Gomori's trichrome staining.

46 Conclusion. This study may provide an effective and low-cost wound dressings to assist skin 47 regeneration for clinical use. 
52 53

Biocomposites, biocompatible and/or eco-friendly composites, can be formed by different varieties of natural and synthetic polymers including polysaccharides, proteins and biodegradable synthetic polymers. Generally, biocomposite materials have better structural properties than either constituent material alone. Therefore, biocomposite materials are often used in contact with living tissues such as scaffolds for cell-based therapy, biomedical implants and controlled drug delivery devices. Collagen based materials are the most well-known biocomposites in clinical use. Collagen-based wound dressings have been applied in the treatment of burn and ulcer patients over the last 30 years (Doillon \& Silver 1986; Peters 1980). Highly innovative tissue-engineered skin substitutes have been developed to mimic normal skin recently with melanocytes, a capillary-like network, sensory innervation and adipose tissue (Bechetoille et al. 2007; Regnier et al. 1997; Tremblay et al. 2005; Trottier et al. 2008). By designing and incorporating specific therapeutic factors in skin substitutes, the promotion of wound healing as well as reduction of morbidity and mortality for large wounds may be achieved. The concept of design for the tissue engineered skin equivalent is based on existing models comprising a stratified epithelium grown on a matrix populated with dermal fibroblasts (el-Ghalbzouri et al. 2002). The biomaterials used for supporting skin cell growth include natural biodegradable polymers such as collagen and gelatin, as well as synthetic biodegradable polymers such as $\alpha$-polyester and poly( $\varepsilon$-caprolactone) (PCL) (Hajiali et al. 2011; $\mathrm{Ng}$ et al. 2004).

For the demand of the durability, elasticity, cosmetic appearance of normal skin and wound repair, several functional dermal layers were developed. Integra ${ }^{\circledR}$ artificial skin is a bi-layered structure consisting a dermal replacement layer covered with a silicone sheet as an outer layer. The dermal layer includes a porous fiber matrix with cross-linked bovine tendon collagen and glycosaminoglycan (chondroitin-6-sulfate) (Burke 1984; Burke 1987; Burke et al. 1981; Yannas \& Burke 1980). Comp Cult Skin ${ }^{\circledR}$ is a type of composite cultured skin consisting of neonatal keratinocytes and fibroblasts cultured in bovine type-I collagen scaffold. Apligraf ${ }^{\circledR}$ is a bi-layered living skin consisting an epidermal layer of neonatal keratinocytes and a dermal layer composed by neonatal fibroblasts in a type I bovine collagen gel (Bell et al. 1981; Trent \& Kirsner 1998; Wilkins et al. 1994).

The dermal components for most of these modified co-cultured skin constructs are mainly composed of collagen. However, pure collagen products are fragile and have difficulty in handling during clinical applications. To solve this problem, biodegradable polymers such as PCL were incorporated with collagen to increase the mechanical strength, which shows better resistance to external force for wound treatment. On the other hand, the well designed collagen scaffolds have been proven to cancel the skin wound contraction and prevent scar formation formed by contractile cells (Dai et al. 2004; Dai et al. 2009; Powell et al. 2008; Soller et al. 2012; Yannas et al. 1989). Meanwhile, animal studies also revealed that the wound size was effectively reduced by the use of 
88

89

90

91

92

93

94

95

96

97

98

99

100

101

102

103

104

105

106

107

108

109

110

111

112

113

114

115

116

117

118

119

120

121

122

123

collagen in vivo (Dai et al. 2004; Dai et al. 2009; Powell et al. 2008; Soller et al. 2012; Yannas et al. 1989). It may be associated with the fast growing epidermal layer of mice. In our previous study (Dai et al. 2004; Dai et al. 2009), we developed collagen:PCL (C/P) biocomposites in two ratios (1:8 and 1:20). They both exhibited a similar porous structure that facilitated cell proliferation. Meanwhile, the smaller pore size may prevent the direct contact between keratinocytes and fibroblasts, and allow for cell interaction via signaling through existing pores. It is worth noting that collagen-based wound dressings were expensive. To solve this problem, we chose gelatin, the degradation of collagen, for the preparation of skin biocomposites. Therefore, the purpose of this study was to prepare a cost-effective, mechanically strong and biodegradable biocomposites based on gelatin, collagen, and PCL (G/C/P). Moreover, G/C/P biocomposites with a lower collagen content were designed and tested in this study because of good cell attachment and proliferation in our preliminary testing. Therefore, high and low GC mats with two different ratios of PCL were fabricated. The structure, thermal characteristics and biocompatibility were evaluated by in vitro testing. The potential in promoting large-sized wound healing was confirmed in the full-thickness skin defect model of nude mice.

\section{MATERIALS AND METHOD}

\section{Preparation of G/C/P and C/P biocomposites}

The preparation of the G/C/P and C/P biocomposites was listed in Table 1 . Aliquots of type $\mathrm{B}$ gelatin (from bovine skin, Sigma-Aldrich, St Louis, Mo) with specific concentration of collagen (Sigma-Aldrich, St Louis, Mo) solution was prepared by dissolving gelatin in double distilled water followed by mixing collagen (dissolved in acetic acid) to produce two ratios of collagen in gelatin/collagen biocomposites respectively. The dissolution of gelatin/collagen was facilitated by stirring using a heating magnetic stirrer in a $25 \mathrm{ml}$ glass shell vial at the temperature of $40^{\circ} \mathrm{C}$. After complete dissolution, aliquots $(0.25 \mathrm{ml})$ of the gelatin/collagen solution were added to $7 \mathrm{ml}$ glass vials followed by elimination of air bubbles and frozen at $-20^{\circ} \mathrm{C}$ for approximately $45-50$ minutes. In the second stage, samples were transferred to a freezer at $-72^{\circ} \mathrm{C}$ for 35 minutes. The frozen samples were placed in a freeze dryer $\left(\right.$ Edwards Modulyo $\left.{ }^{\circledR}\right)$ at $-44^{\circ} \mathrm{C}$ under 42 mbar vacuum for 24 hours to prepare for the $\mathrm{G} / \mathrm{C}$ mats. Aliquots $(0.5 \mathrm{ml})$ of $\mathrm{PCL}(\mathrm{Mw}=115000$, Solvay Interox, Warrington, UK) /dichloromethane (DCM with HPLC grade, Fisher Scientific, UK) solution were added carefully to the freeze dried $\mathrm{G} / \mathrm{C}$ mats with low collagen content to produce $\mathrm{GC}_{\mathrm{L}} \mathrm{P}_{\mathrm{L}}$ $(\mathrm{G} / \mathrm{C}: \mathrm{PCL}$ is $1: 8)$ and $\mathrm{GC}_{\mathrm{L}} \mathrm{P}_{\mathrm{H}}(\mathrm{G} / \mathrm{C}: \mathrm{PCL}$ is $1: 20)$ biocomposites respectively, whereas aliquots $(0.5 \mathrm{ml})$ of PCL/dichloromethane (DCM) solution were added to the freeze dried gelatin/ collagen mats with high collagen content to produce $\mathrm{GC}_{\mathrm{H}} \mathrm{P}_{\mathrm{L}}(\mathrm{G} / \mathrm{C}: \mathrm{PCL}$ is $1: 8)$ and $\mathrm{GC}_{\mathrm{H}} \mathrm{P}_{\mathrm{H}}(\mathrm{G} / \mathrm{C}: \mathrm{PCL}$ is 1:20) biocomposites respectively. The vials were kept for 30 minutes and then removed the lids to allow solvent evaporation overnight. 
124 On the other hand, C/P biocomposite was fabricated described by previous study (Hajiali et al. 125 2011). Briefly, collagen solution was prepared in 1\% acetic acid by stirring with a magnetic stirrer 126 overnight at room temperature. Aliquots $(0.25 \mathrm{ml})$ of the collagen solution were added to $7 \mathrm{ml}$ glass 127 shell vials (Fisher Scientific) and frozen at $-20^{\circ} \mathrm{C}$ for approximately $45-50 \mathrm{~min}$. Samples were 128 transferred to a freezer at $-70^{\circ} \mathrm{C}$ for $35 \mathrm{~min}$ before freeze drying. Aliquots $(0.5 \mathrm{ml})$ of a solution of 129 PCL in DCM were added carefully to the freeze dried collagen mats to prepare 1:8, 1:20 130 collagen:PCL materials, respectively. The vials were kept stopped for $30 \mathrm{~min}$ before removing the 131 lids to allow solvent evaporation overnight. The component ratios of the four G/C/P and C/P 132 biocomposites are shown in Table 1.

\section{Protein release from G/C/P biocomposites}

134 To determine the release of gelatin and collagen from biocomposites $(n=3)$, the bicinchoninic acid (BCA) assay was used to estimate the amount of protein release from $\mathrm{G} / \mathrm{C} / \mathrm{P}$ biocomposites after incubation in phosphate-buffered saline (PBS) at $37^{\circ} \mathrm{C}$ for 12 days. Individual samples were added to $7 \mathrm{ml}$ glass shell vials containing $1 \mathrm{ml}$ PBS and then incubated at $37^{\circ} \mathrm{C}$ in a water bath. The release media was replaced completely by fresh PBS periodically and analysed for total protein content using the BCA assay. The absorbance of the calibration samples measured at 562 $\mathrm{nm}$ was used to produce a calibration curve used to calculate the protein (gelatin/collagen) concentration of the test samples.

\section{Thermal analysis by differential scanning calorimetry (DSC)}

The thermal characteristics of $\mathrm{GC}_{\mathrm{L}} \mathrm{P}_{\mathrm{L}}, \mathrm{GC}_{\mathrm{L}} \mathrm{P}_{\mathrm{H}}, \mathrm{GC}_{\mathrm{H}} \mathrm{P}_{\mathrm{L}}$, and $\mathrm{GC}_{\mathrm{H}} \mathrm{P}_{\mathrm{H}}$, biocomposites with weight between 2-10 mg were recorded using a Perkin-Elmer Pyris Diamond differential scanning calorimeter. All the samples were lightly pressed into the bottom of the pan to ensure good thermal contact. Sealed DSC pans were used in the study. Triplicate samples were heated at a rate of $10^{\circ} \mathrm{C} / \mathrm{min}$ from $10^{\circ} \mathrm{C}$ to $100^{\circ} \mathrm{C}$. Peak melting temperature $(\mathrm{Tm})$ and heat of fusion data for the PCL component of the materials were determined using the built-in software of the DSC. The latter measurement was subsequently used to estimate the percentage crystallinity of PCL in the composites from the reported heat of fusion of $139.5 \mathrm{~J} / \mathrm{g}$ for fully crystalline PCL (Burke 1987). Indium was used as a standard.

\section{The tensile strength analysis by a universal testing machine}

The mechanical analysis was conducted on $\mathrm{GC}_{\mathrm{L}} \mathrm{P}_{\mathrm{H}}$ and $\mathrm{C} / \mathrm{P}$ (1:20 ratio) biocomposites using a universal testing machine (Instron) under axial loading. The biocomposite specimens were cut as the suitable size of rectangular block and were carefully clamped at the center of the cross-head with its end faces exactly perpendicular to the longitudinal axis. The crosshead speed of 50 
$157 \mathrm{~mm} / \mathrm{min}$ was applied for this test. The tensile strength (MPa) was calculated as the force at failure 158 divided by the cross-sectional area of the biocomposite. Results were the average from 3-6 159 measurements and analyzed by one-way analysis of variance and the $t$-test $(\mathrm{P}<0.05)$.

\section{Observation of porous structure by scanning electron microscopy (SEM)}

161 The scanning electron microscope was used to observe the surface morphology of $\mathrm{G} / \mathrm{C} / \mathrm{P}$ 162 biocomposites. Samples were attached to aluminum SEM stubs using carbon tabs (Agar 163 Scientific). Specimens were sputter coated with gold prior to examination using a HITACHI ${ }^{\circledR}$ S$1643000 \mathrm{~N}$ scanning electron microscope.

\section{Cell culture on $\mathbf{G} / \mathbf{C} / \mathbf{P}$}

166 Primary human epidermal keratinocytes (PHEK) and primary human dermal fibroblasts 167 (PHDF) were isolated and primarily cultured from the donated human foreskin samples after the 168 surgery of circumcision in the study, which were approved by the institutional review board (IRB). 169 The study protocol was reviewed and approved by the Institutional Review Board (IRB) in the TriService General Hospital, R.O.C. (TSGHIRB No.: 100-05-251). Then the written informed consent was obtained from each donor. EpiLife ${ }^{\circledR}$ HKM (Cat No.M-EPIcf-500 with addition of $0.06 \mathrm{mM}$ calcium chloride and HKGS kit: Cat No.S-001-5) was used for keratinocyte culture. The cell isolation from skin samples, cell expansion, and cell counting followed those described previously (Burke, 1984).

PHEK (child foreskin; P4) were seeded on the top surface of $\mathrm{G} / \mathrm{C} / \mathrm{P}(1: 8$ and 1:20) and $\mathrm{C} / \mathrm{P}$ biocomposites and 24-well tissue culture plastics (TCP) at a cell density of $1.7 \times 10^{5}$ or cells per density of $2.0 \times 10^{4}$ cells per $\mathrm{cm}^{2}$ for up to 10 days. Human adipose-derived stem cells (ASCs; passages 3-4) were seeded on the biocomposites and 24-well TCP at a cell density of 2.0x $10^{4}$ cells per $\mathrm{cm}^{2}$ for up to 12 days. Trypsin-EDTA solution was used for cell detachment followed by cell counting at 1, 3, 6, and 9 days for PHEK and cell at 1, 4, 7, and 10 days for PHDF using a Weber's haemocytometer. The experiments were repeated at least twice with similar results.

The adhesion, growth, and distribution of cells seeded on $\mathrm{G} / \mathrm{C} / \mathrm{P}$ biocomposites were investigated using the immunohistochemical assay. PHEK (child foreskin; P4) were seeded on the top surface of G/C/P biocomposites (1:8 and 1:20), C/P biocomposites and 24-well tissue culture plastics (TCP) at a cell density of $1.7 \times 10^{5}$ cells per $\mathrm{cm}^{2}$ for time intervals up to 9 days. PHEK on

$187 \mathrm{G} / \mathrm{C} / \mathrm{P}$ biocomposites (1:8 and 1:20) at 1,3, and 6 days were labeled with the (primary) monoclonal rabbit anti-human cytokeratin (CK)-14 1:100 (Bioworld Technology), and the (secondary) rhodamine-conjugated polyclonal goat anti-rabbit IgG 1:200 (Chemicon, Billerica, Mass) examined under a fluorescent microscope. 
191

192

193

194

195

196

197

198

200

201

202

203

204

205

206

207

208

209

210

211

212

213

214

215

216

217

218

219

220

221

222

223

224

225

PHDF (adult foreskin; P3-4) were seeded on the top surface of 1:8 and 1:20 GC10, GC25 and collagen:PCL biocomposites and TCP (24-well tissue culture plastics) at a cell density of $2.0 \times 10^{4}$ cells per $\mathrm{cm}^{2}$ for time intervals up to 10 days. PHDF on G/C/P biocomposites (1:8 and 1:20) at 1 , 7 , and 10 days were labeled with the (primary) monoclonal mouse anti-human $\alpha$-tubulin antibody 1:200 (Cat No.sc-5286; Santa Cruz Biotechnology, Inc.), and the (secondary) fluorescein (FITC)conjugated polyclonal goat anti-mouse IgG 1:100 (Lot No.62686; Jackson ImmunoResearch Laboratories, Inc., USA) and examined under the fluorescent microscope.

\section{Preparation of human adipose-derived stem cells (ASCs)-seeded G/C/P biocomposites for animal experiments}

Human adipose tissues were obtained using lipoaspirate after syringe-assisted liposuction from abdomens of adult Taiwanese female patients who had no systemic metabolic diseases or lipid disorders. The procedures and protocols were conducted at the Tri-Service General Hospital, Taipei, Taiwan, and were approved by IRB.

The isolated fat tissues were washed using PBS. After washing, the tissues were digested with an equal volume of PBS including $0.075 \%$ type I collagenase (Sigma-Aldrich Company Ltd, Poole, UK) at $37^{\circ} \mathrm{C}$ for 1 hour. After centrifugation at $2500 \mathrm{rpm}$ for 10 minutes, the cell pellet was resuspended in Dulbecco modified Eagle medium-low glucose (DMEM-LG; Invitrogen) containing $10 \%$ fetal bovine serum (FBS; Invitrogen) and 1\% penicillin-streptomycin (Invitrogen), and placed in the incubator. After 1 day of culture, the dishes were washed with Hanks buffered salt solution (HBSS; Thermo Scientific, Agawam, Mass) to discard blood cells and nonadhesive cells and fresh culture medium was then added. The medium was refreshed every 3 days. When the cells reached $70 \%$ to $90 \%$ confluence, the cells were trypsinized (0.25\% trypsin; Sigma), neutralized with cultured medium and then passaged at a ratio of 1:3. Cells of passages 3 to 4 were used in the experiments.

$\mathrm{G} / \mathrm{C} / \mathrm{P}$ biocomposites were cut to fit 12 -well tissue culture plastics and then placed into the wells of TCP. For each well, human adipose-derived stem cells (ASCs) at a cell density of $10^{6}$ cells per $\mathrm{cm}^{2}$ were seeded onto the biocomposite with the addition of cultured medium. After incubation for 24 hours, the ASC-seeded biocomposite was washed with HBSS to remove the culture medium and nonattached cells.

\section{Animal model and wound healing experiments}

A skin wound healing model of nude mice was employed (Huang et al. 2012). All mice were acquired, housed, and studied under a protocol approved by the Institutional Animal Care and Use Committee of National Defense Medical Center, Taiwan, R.O.C. The three eight-week-old nude mice (BALB/c-nu; BioLASCO) were chosen for each group including $\mathrm{GC}_{\mathrm{L}} \mathrm{P}_{\mathrm{H}}$ scaffold only and $\mathrm{GC}_{\mathrm{L}} \mathrm{P}_{\mathrm{H}}$ scaffold seeded with ASCs in this study. All of the surgical instruments were sterilized and 
226 the surgical procedures were performed under laminar flow. The surgical sites were sterilized with 227 Easy Antiseptic Liquid 2\% (Panion \& BF, Taipei, Taiwan) before surgery. After anesthesia, a 228 square of full-thickness cutaneous wound $(12 \mathrm{~mm} \times 12 \mathrm{~mm})$ was made by surgery using scalpel 229 on each dorsum of the hind thighs, followed by grabbing, pulling the region with a forceps, and 230 excising of the full-thickness tissue with scissors.

231 The wounds were divided into the following two groups: blank $\mathrm{GC}_{\mathrm{L}} \mathrm{P}_{\mathrm{H}}$ biocomposite and ASCs232 seeded $\mathrm{GC}_{\mathrm{L}} \mathrm{P}_{\mathrm{H}}$ biocomposites. The $\mathrm{GC}_{\mathrm{L}} \mathrm{P}_{\mathrm{H}}$ biocomposites (0.1-0.2 mm thick) for ASCs seeding 233 were used. Both grafts were placed on each wound, sewn with 6 to 8 stitches using NC125L Nylon 234 5-0 surgical sutures (UNIK, Taipei, Taiwan), and covered with Tegaderm films (3M Health Care, $235 \mathrm{MN}$ ) to prevent catching, biting, or wound infections. The wounds were continuously observed for 236 a period of 3 weeks. The area of the wounds was blindly measured twice using Image J v1.44p 237 software (http://imagej.nih.gov/ij; NIH, Bethesda, MD, USA). After 2 weeks, the tissues of healed 238 wounds were excised, fixed in $10 \%$ formalin for at least 24 hours at room temperature, 239 subsequently embedded in paraffin, and sectioned in 5- $\mu \mathrm{m}$ increments. The sections were stained 240 with Gomori's trichrome staining and examined by an optical microscope (Olympus BX50, 241 Hamburg, Germany) (Luna, 1992). The collagen component of the extracellular matrix deposited 242 in skin substitutes was stained green.

\section{Statistical analysis}

244 Results were presented as the mean \pm standard deviation of three replicates for each experiment. 245 Statistical analysis was performed using Statistical Package for the Social Sciences, Version 12.0 246 (SPSS Inc., Chicago, Illinois). The statistically significant differences between groups were 247 assessed by one-way ANOVA analysis of variance, followed by Tukey post-hoc test. $P<0.05$ 248 249

\section{RESULTS}

\section{Protein release from the $\mathbf{G} / \mathbf{C} / \mathbf{P}$}

252 The compositions and fabrication of $\mathrm{G} / \mathrm{C} / \mathrm{P}$ biocomposites are present in Table 1 and the 253 cumulative release of protein from the biocomposites is shown in Figure 1 and Table 2. For G/C/P with a lower collagen content, a higher cumulative protein release was present for $\mathrm{GC}_{\mathrm{L}} \mathrm{P}_{\mathrm{L}}$ biocomposite in comparison with $\mathrm{GC}_{\mathrm{L}} \mathrm{P}_{\mathrm{H}}$ group. At 6 hours, the former showed about $78 \%$ average release, whereas the latter showed 52\% average release. The protein was released quickly in 12 hours for both biocomposites but slow down afterwards. The cumulative release (w/w) at 24 hours was $100 \%$ and $76 \%$ for two biocomposites respectively. For $\mathrm{G} / \mathrm{C} / \mathrm{P}$ with a higher collagen content, a higher cumulative release of protein was found for $\mathrm{GC}_{\mathrm{H}} \mathrm{P}_{\mathrm{H}}$ biocomposite relative to $\mathrm{GC}_{\mathrm{H}} \mathrm{P}_{\mathrm{L}}$ 
260 biocomposite. The former exhibited a higher average release rate of about $62 \%$ average release at

2616 hours, compared to $52 \%$ average release of the latter. The average cumulative release (w/w) after

26224 hours was $81 \%$ and $62 \%$ respectively for $\mathrm{GC}_{\mathrm{H}} \mathrm{P}_{\mathrm{H}}$ and $\mathrm{GC}_{\mathrm{H}} \mathrm{P}_{\mathrm{L}}$ biocomposites. The cumulative

263 release reached a plateau for both biocomposites after 24 hours. PCL is the polymer with slow

264 degradation rate and low water uptake and hence $\mathrm{GC}_{\mathrm{L}} \mathrm{P}_{\mathrm{H}}$ showed better collagen and gelatin

265 encapsulation due to high PCL content. Therefore, unencapsulated gelatin or collagen were

266 released within 3 days and the remained gelatin or collagen would be released slowly depending

267 on the PCL degradation rate. In addition, the amount of protein release significantly increased by

268 gelatin amount in G/C/P biocomposites with low PCL content of polymer but no effect in the those

269 with high PCL content of polymer.

270 Thermal and tensile analyses for $\mathbf{G} / \mathrm{C} / \mathrm{P}$ biocomposites

271 The thermal properties of $\mathrm{G} / \mathrm{C} / \mathrm{P}$ biocomposites $(\mathrm{n}=3)$ are listed in Table 3 . For $\mathrm{G} / \mathrm{C} / \mathrm{P}$ made

272 with $\mathrm{GC}_{\mathrm{L}}$ mats, the melting point of the PCL component was close to the value of $60^{\circ} \mathrm{C}$ normally

273 found for pure PCL. The crystallinity of the PCL in these biocomposites $(\mathrm{C} / \mathrm{P}$ and $\mathrm{G} / \mathrm{C} / \mathrm{P})$ was

274 estimated by comparing the fusion heat with that of $100 \%$ crystalline PCL as $-139 \mathrm{~J} / \mathrm{g}$. From our

275 previous DSC study (Dai et al., 2004), the 1:20 collagen:PCL biocomposite displayed the highest

276 crystallinity of $63.5 \pm 3.8 \%$, followed by $48.5 \pm 4.4 \%$ for $1: 8$ collagen:PCL biocomposites. However,

277 the crystallinity of the PCL films prepared by solvent casting was only around $54.2 \pm 5.4 \%$ in

278 comparison with 1:20 w/w collagen:PCL biocomposites at $63.5 \pm 3.8 \%$ (Table 3). For G/C/P

279 biocomposites, the average crystallinity of $\mathrm{GC}_{\mathrm{H}} \mathrm{P}_{\mathrm{H}}$ was found to increase by $2.9 \%$ relative to the

280 solvent cast PCL film. Furthermore, the mean crystallinity of the PCL phase in the higher

281 gelatin/collagen content $(1: 8 \mathrm{w} / \mathrm{w})$ tended to be lower than that of 1:20 films. However, there was

282 no statistically significance between these groups (Paired t-test: $\mathrm{P}=0.173$ ).

283 The mechanical properties of G/C/P vs. G/P are listed in Table 4. The enhanced tensile strength

284 and elongation and lower Young's modulus were detected in $\mathrm{GC}_{\mathrm{L}} \mathrm{P}_{\mathrm{H}}$ when compared with $\mathrm{G} / \mathrm{P}$

285 biocomposites (1:20 mixture).

286

287

288

289

290

291

292

293

\section{Structure of G/C/P biocomposites}

The SEM images of G/C/P biocomposites are shown in Figure 2. From these image, an irregular pore structure $(20-100 \mu \mathrm{m})$ was apparent on the surface of $\mathrm{G} / \mathrm{C} / \mathrm{P}$ biocomposite. The biocomposites with a lower PCL content $\left(\mathrm{GC}_{\mathrm{L}} \mathrm{P}_{\mathrm{L}}\right)$ exhibited more porous structure. On the other hand, biocomposites with a higher collagen content $\left(\mathrm{GC}_{\mathrm{H}} \mathrm{P}_{\mathrm{L}}\right.$ and $\left.\mathrm{GC}_{\mathrm{H}} \mathrm{P}_{\mathrm{H}}\right)$ showed less pore structure when compared to those with a lower collagen content $\left(G_{L} P_{L}\right.$ and $\left.G_{L} P_{H}\right)$. The $G_{H} P_{L}$ biocomposite with highest content of collagen and lowest content of PCL showed a rough, fibrous surface due to the underlying collagen mat structure. The higher ratio of PCL was applied, the 
294 smoother surface was present because smooth overlying areas could be formed by the PCL phase.

295 In addition, the surfaces of biocomposites with higher ratio of collagen seemed to have gel-like

296 material filling the pores. All biocomposites exhibited the rough, fibrous structure of $\mathrm{G} / \mathrm{C}$ mat

297 overlaid by the smooth PCL phase. Little difference in morphology was observed.

\section{Attachment and proliferation of PHEK, PHDF and ASC on G/C/P biocomposites}

299 The attachment and proliferation of PHEK, PHDF and ASCs on G/C/P are shown in Figure 3.

300 The number of PHEK on $\mathrm{GC}_{\mathrm{L}} \mathrm{P}_{\mathrm{H}}$ and $\mathrm{GC}_{\mathrm{H}} \mathrm{P}_{\mathrm{L}}$ was greater than that on the other biocomposites at 1 301 day. The cell density of PHEK was greater on $\mathrm{C} / \mathrm{P}$ biocomposites (1:8) than on $\mathrm{G} / \mathrm{C} / \mathrm{P}$ 302 biocomposites at 3 and 6 days $(\mathrm{P}<0.05)$. PHEK almost had equal cell density on $\mathrm{C} / \mathrm{P}$ and $\mathrm{G} / \mathrm{C} / \mathrm{P}$ 303 biocomposites at 9 days $(\mathrm{P}>0.05)$. Moreover, the $\mathrm{GC}_{\mathrm{L}} \mathrm{P}_{\mathrm{L}}$ biocomposite appeared to have the 304 greatest number of cells at 9 days. However, no significant differences were present among these 305 groups. The number of $\mathrm{PHDF}$ on $\mathrm{GC}_{\mathrm{H}} \mathrm{P}_{\mathrm{L}}$ was greater than on the other biocomposites after 1 day $306(\mathrm{P}<0.05)$. There was no significant difference in the cell number among all groups at 4, 7, and 10 307 days. Results of cell proliferation on different biocomposites showed that PHEK exhibited faster 308 cell growth than PHDF at 1 day. Meanwhile, the numbers of ASCs on different biomaterials were 309 also investigated. Cell proliferation on $\mathrm{GC}_{\mathrm{L}} \mathrm{P}_{\mathrm{H}}$ was similar to the other groups in 10 days. Based 310 on these results, PHEK, PHDF and ASCs well attached and proliferated on all G/C/P 311 biocomposites.

312 The morphology of PHEK and PHDF is shown in Figure 4. Keratinocytes with similar granular 313 shape were observed on the biocomposites. A higher expression of cytokeratin-14, the structural 314 protein of mature keratinocyte, was induced as the incubation time increased. On the other hand, $315 \alpha$ tubulin, a major component of fibroblast cytoskeleton, was stained and appeared as the spindle316 like shape. As the time increased, more $\alpha$ tubulin was expressed in PHDFs. The fluorescent 317 expressions of cytokeratin-14 and $\alpha$ tubulin were parallel to the numbers of attached and 318 proliferated keratinocytes shown in Figure 3. In addition, the $\alpha$ tubulin expression of fibroblasts 319 and cytokeratin-14 expression of keratinocytes seeded on $\mathrm{GC}_{\mathrm{L}} \mathrm{P}_{\mathrm{H}}$ and $\mathrm{GC}_{\mathrm{H}} \mathrm{P}_{\mathrm{L}}$ were higher than 320 those of other groups at three days. Therefore, the $\mathrm{GC}_{\mathrm{L}} \mathrm{P}_{\mathrm{H}}$ biocomposite with the lowest collagen 321 content in the 4 GCP scaffolds was selected as the skin substitute for the pilot animal study because 322 gelatin was a cheaper material than collagen.

\section{In vivo animal study}

324 Rapid wound closure was observed in the both groups covered with $\mathrm{GC}_{\mathrm{L}} \mathrm{P}_{\mathrm{H}}$ biocomposites in 325 comparison with the control group, as shown in Figure 5. In both groups covered with $\mathrm{GC}_{\mathrm{L}} \mathrm{P}_{\mathrm{H}}$ 326 biocomposites, the wound size dramatically decreased apparently was observed from 8 to 12 days 327 and then gradually decreased until 21 days. The rate of wound healing was almost the same for 328 both groups within 16 days. However, the wound healing based on wound area exhibited statistical 
329

330

331

332

333

334

335

336

337

338

339

340

341

342

343

344

345

346

347

348

349

350

351

352

353

354

355

356

357

358

359

360

361

362

363

364

difference at day $21(\mathrm{P}<0.05)$. The incomplete wound closure also observed even up to 21 days for the group covered with $\mathrm{GC}_{\mathrm{L}} \mathrm{P}_{\mathrm{H}}$ only but not ASC-seeded $\mathrm{GC}_{\mathrm{L}} \mathrm{P}_{\mathrm{H}}$. Furthermore, Gomori's trichrome staining was performed in control, groups covered with $\mathrm{GC}_{\mathrm{L}} \mathrm{P}_{\mathrm{H}}$ only and ASC-seeded $\mathrm{GC}_{\mathrm{L}} \mathrm{P}_{\mathrm{H}}$, as presented in Figure 6. The open wound covered with $\mathrm{GC}_{\mathrm{L}} \mathrm{P}_{\mathrm{H}}$ only exhibited loose collagen deposition even after 14 days (Figure $6 \mathrm{~B} \& \mathrm{E}$ ). In the $\mathrm{ASC}$-seeded $\mathrm{GC}_{\mathrm{L}} \mathrm{P}_{\mathrm{H}}$ group, complete wound closure with differentiated epidermis and abundant dermal parallel-arranged fibrous collagen deposition was observed at 14 days (Figure 6C\&F). At a larger magnification, the ASCseeded $\mathrm{GC}_{\mathrm{L}} \mathrm{P}_{\mathrm{H}}$ group showed the largest thickness of epidermis, followed by the $\mathrm{GC}_{\mathrm{L}} \mathrm{P}_{\mathrm{H}}$ only group, and then the open wound. The thick epidermis layer was obviously observed in the outside portion of the wound for the ASC-seeded $\mathrm{GC}_{\mathrm{L}} \mathrm{P}_{\mathrm{H}}$.

\section{DISCUSSION}

Based on the lower collagen content, we developed a cheaper skin substitute integrating the advantages of natural and synthetic biopolymers to promote the growth of skin cells in this study. Berillis has mentioned that collagen-based biopolymers are critical for tissue engineering and regenerative medicine due to its superior biocompatibility and low immunogenicity which is depended on the source of collagen (Berillis, 2015). Collagen not only provides the building block for elastin and collagen fiber formation, but also acts as ligands for dermal fibroblasts to stimulate the production of new collagen, elastin and hyaluronic acid (Sibilla et al. 2015). In addition, collagen hydrolysate exhibits bioactivities including antihypertensive activity, lipid-lowering activity, as well as reparative properties in injured skin (Fan et al. 2013). Gelatin, which is derived from the partial hydrolysis of collagen, could be effective in promotion of granulation and epithelialization in the skin wound and also modulate drug delivery in targeted tissues (Albuquerque-Júnior et al. 2009; Dantas et al. 2011; Ikada \& Tabata 1998). Gelatin contains integrin binding sites for cell adhesion with the characteristics of low cost, natural abundance, biodegradability and biocompatibility (Lakshminarayanan et al. 2014; Ma et al. 2005). Poly- $\varepsilon$ caprolactone (PCL), approved by the Food and Drug Administration (FDA), is a hydrophobic, biodegradable and biocompatible synthetic polyester and which are widely applied in drug delivery and tissue repair (Spearman, 2014). Therefore, our approach could combine the characteristics including cell binding properties of natural polymers such as gelatin and collagen and the structural stability of PCL. These composite films are highly flexible which may allow effective draping over the wound site to improve the graft application.

Tissue engineering scaffolds should have enough residence time for tissue development. PCL was chosen in this study because of its long resorption time, over 1 year (Pitt et al., 1981). Additionally, the stability of PCL reduces the possible toxicological effect associated with chemical crosslinking of natural polymers. Tear resistance is also conferred by PCL which 
365 facilitates the manipulation during surgery. We also expect the stability of PCL may inhibit wound

366

367

368

369

370

371

372

373

374

375

376

377

378

379

380

381

382

383

384

385

386

387

388

389

390

391

392

393

394

395

396

397

398

399

400 contraction by fibroblasts for optimal dermal regeneration of full thickness wounds (Werner et al. 1994). However, PCL is known to be susceptible to acid and enzymatic degradation (Leffler \& Muller 2000). Mochizuki et al. reported that certain lipases enhanced the degradation of polycaprolactone (PCL) when compared with incubation in buffer only (Mochizuki et al. 1995).

Based on DSC data, the degree of PCL crystallinity was greater for the biocomposites with a lower $\mathrm{G} / \mathrm{C}$ content in which implicated that the gelatin/collagen phase could impede PCL crystallization. The notable reduction of $\mathrm{PCL}$ crystallinity in the biocomposites with $\mathrm{GC}_{\mathrm{H}}$ mat may be associated with the effect of $\mathrm{GC}_{\mathrm{H}}$ mat to interfere with the nucleation of PCL crystals. This phenomenon may also facilitate hydrolytic chain scission in this semi-crystalline polymer. In addition, the solvent evaporation may be conducive to develop high crystallinity due to the differences of crystal nucleation process between the pellet and the thin membranous form of PCL. Gelatin may not be able to develop a very strong architecture during the process of lyophilisation thereby exerts a minor effect on crystal nucleation of PCL phase. From DSC results, the similar GC content had almost the same percentage of crystallinity in PCL (Table 1). Therefore, collagen content may play a critical role in the degree of the PCL crystal nucleation pattern.

As the PCL content decreased, C/P biocomposites showed a more open, porous structure in a previous study (Coombes et al. 2002; Dai et al., 2004). In previous study, the cell attachment and spreading on collagen:PCL composites found that 1:8 composites exhibited a greater masking or coating effect of the fibrous structure, whereas 1:20 composites showed a roughened, dimpled surface texture and separated pores. A similar trend in G/C/P was observed based on SEM images of this study. The pore number and size were slightly greater for the lower collagen content. Our previous study reported that the pore number and size seemed to increase after incubation in PBS, suggesting that protein may be released from the sub-superficial layers of the biocomposites (Dai et al. 2004). As shown in Figure $1, \mathrm{GC}_{\mathrm{H}} \mathrm{P}_{\mathrm{L}}$ and $\mathrm{GC}_{\mathrm{L}} \mathrm{P}_{\mathrm{H}}$ remained higher gelatin/collagen amount than other two G/C/P biocomposites after 24 hours incubation and Figure 3 also indicated that $\mathrm{GC}_{\mathrm{H}} \mathrm{P}_{\mathrm{L}}$ and $\mathrm{GC}_{\mathrm{L}} \mathrm{P}_{\mathrm{H}}$ had slightly better cell attachment than others. Therefore, cell attachment and proliferation may be more related the amount of remained gelatin or collagen rather surface morphology.

The cost effect, quality of materials, and simple fabrication procedures are critical for the development of tissue-engineered skin model. Although collagen is more bioactive than gelatin, the price for collagen is much higher than that of gelatin. Therefore, the replacement of collagen by gelatin or other biomaterials may be cost-effective. However, pure gelatin was relatively fragile and weak during the lyophilization procedure, which made the fabrication difficult to control and caused one-third failure preparation rate in the early stage of this work. From Table 3, the C/P biocomposite also showed lower tensile strength, lower elongation, and higher Young's modulus 
401 when compared with $\mathrm{GC}_{\mathrm{L}} \mathrm{P}_{\mathrm{H}}$ biocomposites. Therefore, the mixture of gelatin and collagen as $\mathrm{G} / \mathrm{C}$ 402 mat was employed. The G/C/P biocomposites were found to possess proper biocompatibility.

403 ASCs are widely used in tissue engineering and stem cell therapy because of their advantages 404 in accessibility and immunosuppressive characteristics (Gonzalez-Rey et al. 2009). Effective 405 would healing was improved by ASCs in literature (Lam et al. 2013; Lin et al. 2013; Nauta et al. 2013; Shokrgozar et al. 2012). The adipose lineage cells could serve as a new cell source that promoted reepithelialization and angiogenesis in dermal wound healing from previous literature (Ebrahimian et al. 2009). However, stem cells directly applied on the wound site are not well survived (Lam et al. 2013), which reduces the efficacy of wound closure. An abundant amount of dermal collagen deposition was shown by histological staining. These findings suggested that tracing dye has to label the cells, which will be a future subject of study. In addition, G/C/P biocomposites may further be incorporated with growth factors to accelerate the wound repair (Shin \& Peterson 2013).

Finally, we hypothesize that the stronger mechanical strength of $\mathrm{G} / \mathrm{C} / \mathrm{P}$ may help resisting the contraction generated by fibroblasts and prevent possible scar formation. Therefore, the G/C/P biocomposites (in particular $\mathrm{GC}_{\mathrm{L}} \mathrm{P}_{\mathrm{H}}$ ) with advantages in biocompatibility as well as mechanical properties are potential scaffolds for clinical wound treatment.

\section{CONCLUSIONS}

$\mathrm{G} / \mathrm{C} / \mathrm{P}$ biocomposites were fabricated and characterized as tissue engineered skin substitutes in this study. A similar fibrous/porous structure and thermal properties were present in G/C/P biocomposites. A reasonable mechanical strength and biocompatibility in vitro were achieved for the $\mathrm{G} / \mathrm{C} / \mathrm{P}$ biocomposites containing the lower collagen content $\left(\mathrm{GC}_{\mathrm{L}} \mathrm{P}\right)$. Furthermore, the rapid closure of the skin wounds in nude mice were observed for those treated with $\mathrm{GC}_{\mathrm{L}} \mathrm{P}_{\mathrm{H}}$ only or ASCseeded $\mathrm{GC}_{\mathrm{L}} \mathrm{P}_{\mathrm{H}}$. Therefore, $\mathrm{GC}_{\mathrm{L}} \mathrm{P}_{\mathrm{H}}$ biocomposites could be applied as low cost wound dressings 
429 REFERENCES

430 Albuquerque-Júnior, R.L.C., Barreto, A.L.S., Pires, J.A., Reis, F.P., Lima, S.O., Ribeiro, M. A.G.,

431

432

433

434

435

436

437

438

439

440

441

442

443

444

445

446

447

448

449

450

451

452

453

454

455

456

457

458

459

460

461

462

463

Cardoso, J.C., 2009. Effect of bovine type-I collagen-based films containing red propolis on dermal wound healing in rodent model. Int. J. Morphol. 27, 1105-1110.

Arvanitoyannis I, Psomiadou E, Nakayama A, Aiba S, Yamamoto N. 1997. Edible films made from gelatin, soluble starch and polyols, part 3. Food Chem 60(4):593-604.

Bechetoille N, Dezutter-Dambuyant C, Damour O, Andre V, Orly I, and Perrier E. 2007. Effects of solar ultraviolet radiation on engineered human skin equivalent containing both Langerhans cells and dermal dendritic cells. Tissue Eng 13:2667-2679. 10.1089/ten.2006.0405

Bell E, Ehrlich HP, Buttle DJ, and Nakatsuji T. 1981. Living tissue formed in vitro and accepted as skin-equivalent tissue of full thickness. Science 211:1052-1054.

Berillis P. Marine collagen: Extraction and applications. In: Madhukar S., editor. Research Trends in Biochemistry, Molecular Biology and Microbiology. SM Group; Dover, DE, USA: 2015. pp. 1-13.

Burke, JF. 1984. The effects of the configuration of an artificial extracellular matrix on the development of a functional dermis. In: Trelstad R, ed. The role of extracellular matrix in development. New York: Liss, p 351-355.

Burke JF. 1987. Observations on the development and clinical use of artificial skin--an attempt to employ regeneration rather than scar formation in wound healing. Jpn J Surg 17:431438.

Burke JF, Yannas IV, Quinby WC, Jr., Bondoc CC, and Jung WK. 1981. Successful use of a physiologically acceptable artificial skin in the treatment of extensive burn injury. Ann Surg 194:413-428.

Coombes AG, Verderio E, Shaw B, Li X, Griffin M, and Downes S. 2002. Biocomposites of noncrosslinked natural and synthetic polymers. Biomaterials 23:2113-2118.

Dai NT, Williamson MR, Khammo N, Adams EF, and Coombes AG. 2004. Composite cell support membranes based on collagen and polycaprolactone for tissue engineering of skin. Biomaterials 25:4263-4271. 10.1016/j.biomaterials.2003.11.022

Dai NT, Yeh MK, Chiang CH, Chen KC, Liu TH, Feng AC, Chao LL, Shih CM, Sytwu HK, Chen SL, Chen TM, and Adams EF. 2009. Human single-donor composite skin substitutes based on collagen and polycaprolactone copolymer. Biochem Biophys Res Commun 386:21-25. 10.1016/j.bbrc.2009.05.123

Dantas MD, Cavalcante DR, Araujo FE, Barretto SR, Aciole GT, Pinheiro AL, Ribeiro MA, LimaVerde IB, Melo CM, Cardoso JC, and Albuquerque Junior RL. 2011. Improvement of 
464

465

466

467

468

469

470

471

472

473

474

475

476

477

478

479

480

481

482

483

484

485

486

487

488

489

490

491

492

493

494

495

496

497

498

499

dermal burn healing by combining sodium alginate/chitosan-based films and low level laser therapy. J Photochem Photobiol B 105:51-59. 10.1016/j.jphotobiol.2011.06.009

Doillon CJ, and Silver FH. 1986. Collagen-based wound dressing: effects of hyaluronic acid and fibronectin on wound healing. Biomaterials 7:3-8.

Ebrahimian TG, Pouzoulet F, Squiban C, Buard V, Andre M, Cousin B, Gourmelon P, Benderitter M, Casteilla L, and Tamarat R. 2009. Cell therapy based on adipose tissue-derived stromal cells promotes physiological and pathological wound healing. Arterioscler Thromb Vasc Biol 29:503-510. 10.1161/ATVBAHA.108.178962

el-Ghalbzouri A, Gibbs S, Lamme E, Van Blitterswijk CA, and Ponec M. 2002. Effect of fibroblasts on epidermal regeneration. Br J Dermatol 147:230-243.

Fan J, Zhuang Y, and Li B. 2013. Effects of collagen and collagen hydrolysate from jellyfish umbrella on histological and immunity changes of mice photoaging. Nutrients 5:223233. 10.3390/nu5010223

Gonzalez-Rey E, Anderson P, Gonzalez MA, Rico L, Buscher D, and Delgado M. 2009. Human adult stem cells derived from adipose tissue protect against experimental colitis and sepsis. Gut 58:929-939. 10.1136/gut.2008.168534

Hajiali H, Shahgasempour S, Naimi-Jamal MR, and Peirovi H. 2011. Electrospun PGA/gelatin nanofibrous scaffolds and their potential application in vascular tissue engineering. Int J Nanomedicine 6:2133-2141. 10.2147/IJN.S24312

Huang SP, Hsu CC, Chang SC, Wang CH, Deng SC, Dai NT, Chen TM, Chan JY, Chen SG, and Huang SM. 2012. Adipose-derived stem cells seeded on acellular dermal matrix grafts enhance wound healing in a murine model of a full-thickness defect. Ann Plast Surg 69:656-662. 10.1097/SAP.0b013e318273f909

Ikada Y, and Tabata Y. 1998. Protein release from gelatin matrices. Adv Drug Deliv Rev 31:287301.

Lakshminarayanan R, Sridhar R, Loh XJ, Nandhakumar M, Barathi VA, Kalaipriya M, Kwan JL, Liu SP, Beuerman RW, and Ramakrishna S. 2014. Interaction of gelatin with polyenes modulates antifungal activity and biocompatibility of electrospun fiber mats. Int $\mathrm{J}$ Nanomedicine 9:2439-2458. 10.2147/IJN.S58487

Lam MT, Nauta A, Meyer NP, Wu JC, and Longaker MT. 2013. Effective delivery of stem cells using an extracellular matrix patch results in increased cell survival and proliferation and reduced scarring in skin wound healing. Tissue Eng Part $A$ 19:738-747. 10.1089/ten.TEA.2012.0480

Luna LG. 1992. Histopathological methods and color atlas of special stains and tissue artifacts, 1st edition, American Histolabs, Inc., Gaithersburg, MD.

Lee SY. 1996. Bacterial polyhydroxyalkanoates. Biotechnology and Bioengineering 49:1-14. 
500

501

502

503

504

505

506

507

508

509

510

511

512

513

514

515

516

517

518

519

520

521

522

523

524

525

526

527

528

529

530

531

532

533

534

10.1002/(SICI)1097-0290(19960105)49:1<1::AID-BIT1>3.0.CO;2-P

Leffler CC, and Muller BW. 2000. Influence of the acid type on the physical and drug liberation properties of chitosan-gelatin sponges. Int J Pharm 194:229-237.

Li Shen, Ernst Worrell, Martin Patel. 2010. Present and future development in plastics from biomass. Biofuels Bioprod Bioref 4:25-40.

Lin YC, Grahovac T, Oh SJ, leraci M, Rubin JP, and Marra KG. 2013. Evaluation of a multi-layer adipose-derived stem cell sheet in a full-thickness wound healing model. Acta Biomater 9:5243-5250. 10.1016/j.actbio.2012.09.028

Ma Z, He W, Yong T, and Ramakrishna S. 2005. Grafting of gelatin on electrospun poly(caprolactone) nanofibers to improve endothelial cell spreading and proliferation and to control cell Orientation. Tissue Eng 11:1149-1158. 10.1089/ten.2005.11.1149

Maitz MF. 2015. Applications of synthetic polymers in clinical medicine. Biosurf Biotribol 1:161176

Mochizuki M, Hirami M, Kanmuri Y, Juko K, Tokiwa Y. 1995. Hydrolysis of polycaprolactone fibers by lipase: effects of draw ratio on enzymatic degradation. J. App. Polym. Sci. 55: 289-296.

Nauta A, Seidel C, Deveza L, Montoro D, Grova M, Ko SH, Hyun J, Gurtner GC, Longaker MT, and Yang F. 2013. Adipose-derived stromal cells overexpressing vascular endothelial growth factor accelerate mouse excisional wound healing. Mol Ther 21:445-455. 10.1038/mt.2012.234

$\mathrm{Ng} \mathrm{KW,} \mathrm{Khor} \mathrm{HL,} \mathrm{and} \mathrm{Hutmacher} \mathrm{DW.} \mathrm{2004.} \mathrm{In} \mathrm{vitro} \mathrm{characterization} \mathrm{of} \mathrm{natural} \mathrm{and} \mathrm{synthetic}$ dermal matrices cultured with human dermal fibroblasts. Biomaterials 25:2807-2818. 10.1016/j.biomaterials.2003.09.058

Peters WJ. 1980. Biological dressings in burns--a review. Ann Plast Surg 4:133-137.

Pitt CG, Chasalow FI, Hibionada YM, Klimas DM, Schindler A. 1981. Aliphatic polyesters 1. The degradation of poly( $\varepsilon$-caprolactone) in vivo. J Appl Polym Sci 26: 3779-3787.

Poirier Y, Nawrath C, and Somerville C. 1995. Production of polyhydroxyalkanoates, a family of biodegradable plastics and elastomers, in bacteria and plants. Bio/Technology 13:142150.

Powell HM, Supp DM, and Boyce ST. 2008. Influence of electrospun collagen on wound contraction of engineered skin substitutes. Biomaterials 29:834-843. 10.1016/j.biomaterials.2007.10.036

Regnier M, Staquet MJ, Schmitt D, and Schmidt R. 1997. Integration of Langerhans cells into a pigmented reconstructed human epidermis. J Invest Dermatol 109:510-512.

Spearman SS, Rivero IV, Abidi N. 2014. Influence of polycaprolactone/polyglycolide blended electrospun fibers on the morphology and mechanical properties of polycaprolactone, $J$ 
535

536

537

538

539

540

541

542

543

544

545

546

547

548

549

550

551

552

553

554

555

556

557

558

559

560

561

562

563

564

565

566

567

568

569

570

Appl Polym Sci 131 (9).

Sevigne-Itoiz E, Gasol CM, Rieradevall J, and Gabarrell X. 2015. Contribution of plastic waste recovery to greenhouse gas (GHG) savings in Spain. Waste Manag 46:557-567. 10.1016/j.wasman.2015.08.007

Sibilla S, Godfrey M, Brewer S, Budh-Raja A, Genovese L. 2015. An overview of the beneficial effects of hydrolysed collagen as a neutraceutical on skin properties: scientific background and clinical studies. Open Neutraceutical J 8:29-42.

Shin L, and Peterson DA. 2013. Human mesenchymal stem cell grafts enhance normal and impaired wound healing by recruiting existing endogenous tissue stem/progenitor cells. Stem Cells Trans/ Med 2:33-42. 10.5966/sctm.2012-0041

Shokrgozar MA, Fattahi M, Bonakdar S, Ragerdi Kashani I, Majidi M, Haghighipour N, Bayati V, Sanati $H$, and Saeedi SN. 2012. Healing potential of mesenchymal stem cells cultured on a collagen-based scaffold for skin regeneration. Iran Biomed J 16:68-76.

Soller EC, Tzeranis DS, Miu K, So PT, and Yannas IV. 2012. Common features of optimal collagen scaffolds that disrupt wound contraction and enhance regeneration both in peripheral nerves and in skin. Biomaterials 33:4783-4791. 10.1016/j.biomaterials.2012.03.068

Tremblay PL, Hudon V, Berthod F, Germain L, and Auger FA. 2005. Inosculation of tissueengineered capillaries with the host's vasculature in a reconstructed skin transplanted on mice. Am J Transplant 5:1002-1010. 10.1111/j.1600-6143.2005.00790.x

Trent JF, and Kirsner RS. 1998. Tissue engineered skin: Apligraf, a bi-layered living skin equivalent. Int J Clin Pract 52:408-413.

Trottier V, Marceau-Fortier G, Germain L, Vincent C, and Fradette J. 2008. IFATS collection: Using human adipose-derived stem/stromal cells for the production of new skin substitutes. Stem Cells 26:2713-2723. 10.1634/stemcells.2008-0031

Werner S, Smola H, Liao X, Longaker MT, Krieg T, Hofschneider PH, and Williams LT. 1994. The function of KGF in morphogenesis of epithelium and reepithelialization of wounds. Science 266:819-822.

Wilkins LM, Watson SR, Prosky SJ, Meunier SF, and Parenteau NL. 1994. Development of a bilayered living skin construct for clinical applications. Biotechnol Bioeng 43:747-756. 10.1002/bit.260430809

Yannas IV, and Burke JF. 1980. Design of an artificial skin. I. Basic design principles. J Biomed Mater Res 14:65-81. 10.1002/jbm.820140108

Yannas IV, Lee E, Orgill DP, Skrabut EM, and Murphy GF. 1989. Synthesis and characterization of a model extracellular matrix that induces partial regeneration of adult mammalian skin. Proc Natl Acad Sci U S A 86:933-937. 


\section{Figure Legends}

572 Fig. 1 Cumulative protein release from G/C/P biocomposites in PBS at $37^{\circ} \mathrm{C}$.

573 Fig. 2 SEM images of $\mathrm{GC}_{\mathrm{L}} \mathrm{P}_{\mathrm{L}}, \mathrm{GC}_{\mathrm{L}} \mathrm{P}_{\mathrm{H}}, \mathrm{GC}_{\mathrm{H}} \mathrm{P}_{\mathrm{L}}$, and $\mathrm{GC}_{\mathrm{H}} \mathrm{P}_{\mathrm{H}}$ biocomposites.

574 Fig. 3 Attachment and proliferation of (A) Primary human epidermal keratinocyte (PHEK) 575 and (B) primary human dermal fibroblasts (PHDF) (C) human adipose-derived stem cells 576 (ASCs) grown on G/C/P and C/P biocomposites. The blank wells (tissue culture polystyrene, 577 TCP) served as the control.

578 Fig. 4 Immunohistochemical assay for (A) PHEK grown on four G/C/P biocomposites at 1, 3 579 days and for (B) PHDF grown on four biocomposites at 1, 3 days, as the staining controls 580 lacking primary antibody were present in the second set of columns (in the right side). CK-14 581 was a specific protein for PHEK, whereas alpha tubulin was a specific protein for PHDF. w/o: 582 without (scale bar: $250 \mu \mathrm{m})$.

583 Fig. 5 Comparison of wound closure: (A) the appearance and (B) the area of wound in the 584 full-thickness skin defect of nude mice covered with $\mathrm{GC}_{\mathrm{L}} \mathrm{P}_{\mathrm{H}}$ biocomposites and those seeded 585 with ASCs until 21 days. The untreated wounds were served as the control.

586 Fig. 6 Collagen deposition in the wound bed by Gomori's trichrome staining for the 587 histology of cultured skin model in the groups of (A) open wound (B) $G_{L} P_{H}$ only (C) ASCs588 seeded $\mathrm{GC}_{\mathrm{L}} \mathrm{P}_{\mathrm{H}}(40 \times$; scale bar: $30 \mu \mathrm{m})$ on the full-thickness skin defect of nude mice for 14 589 days. The panels (D) to (F) were the magnified images of the box area (red rectangle) in (A) 590 to $(\mathrm{C})$ respectively $(100 \times$; scale bar: $5 \mu \mathrm{m})$.

591 Supplement S1 Differential scanning calorimetry scan of four G/C/P biocomposites. (Tm: 592 melting temperature; Endo: endothermic; data H: enthalpy) 
Figure 1

Cumulative protein release from G/C/P biocomposites in PBS at $37^{\circ} \mathrm{C}$.

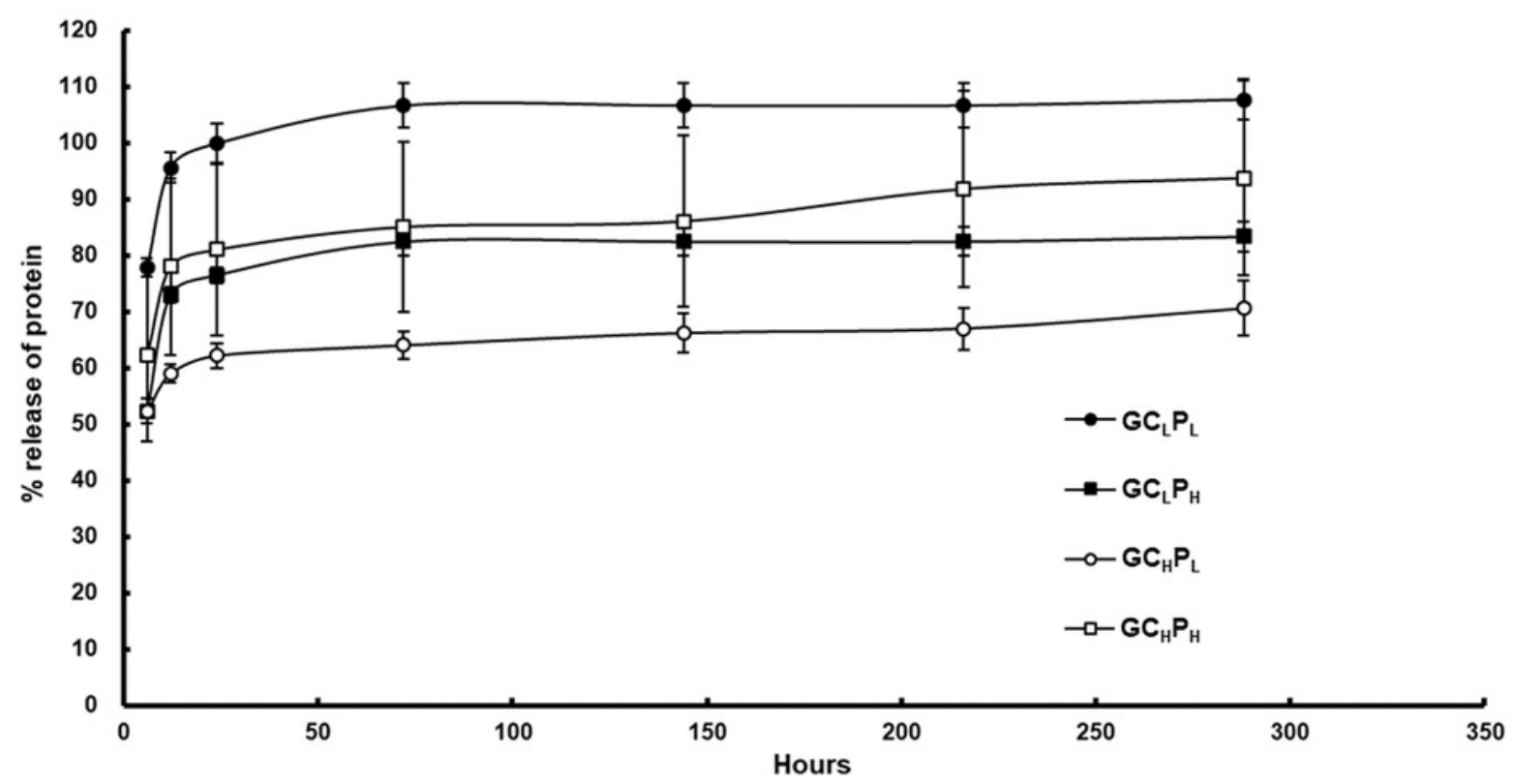


Figure 2

SEM images of $\mathrm{GC}_{L} \mathrm{P}_{\mathrm{L}}, \mathrm{GC}_{\mathrm{L}} \mathrm{P}_{H}, \mathrm{GC}_{\mathrm{H}} \mathrm{P}_{\mathrm{L}}$, and $\mathrm{GC}_{\mathrm{H}} \mathrm{P}_{\mathrm{H}}$ biocomposites. 


\section{Small magnification}
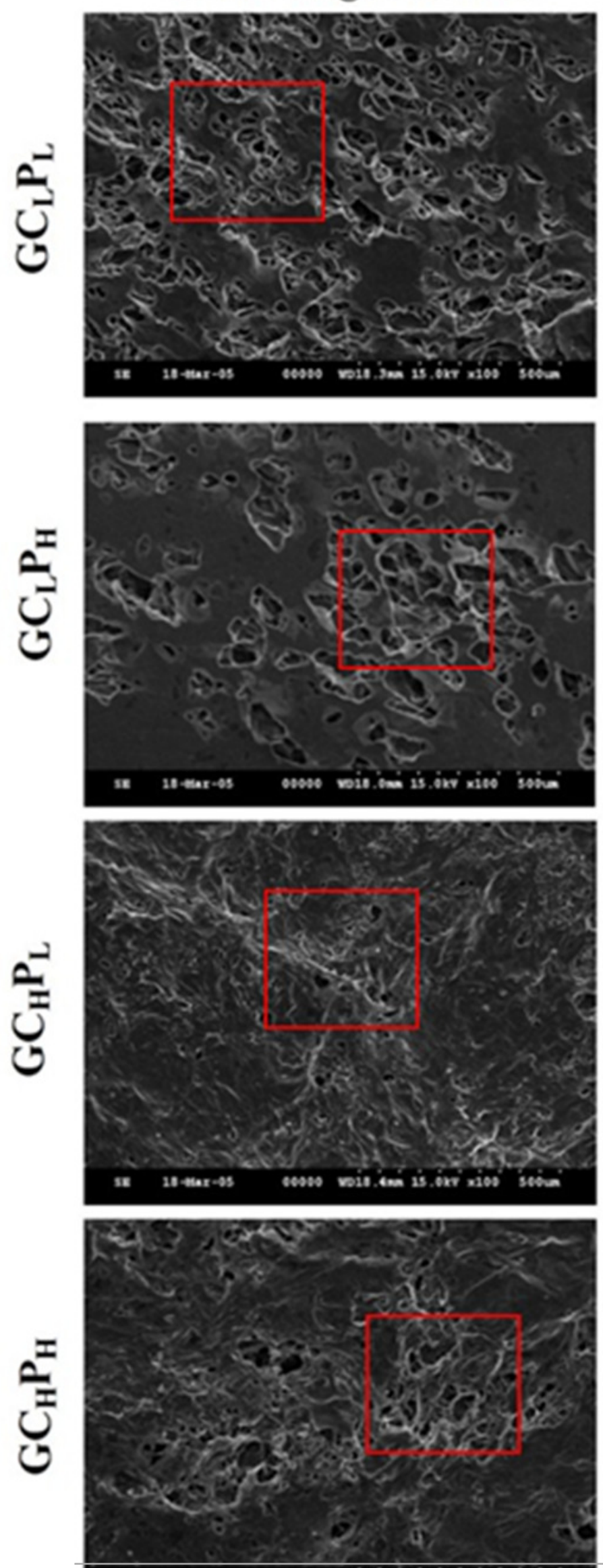

\section{Large magnification}
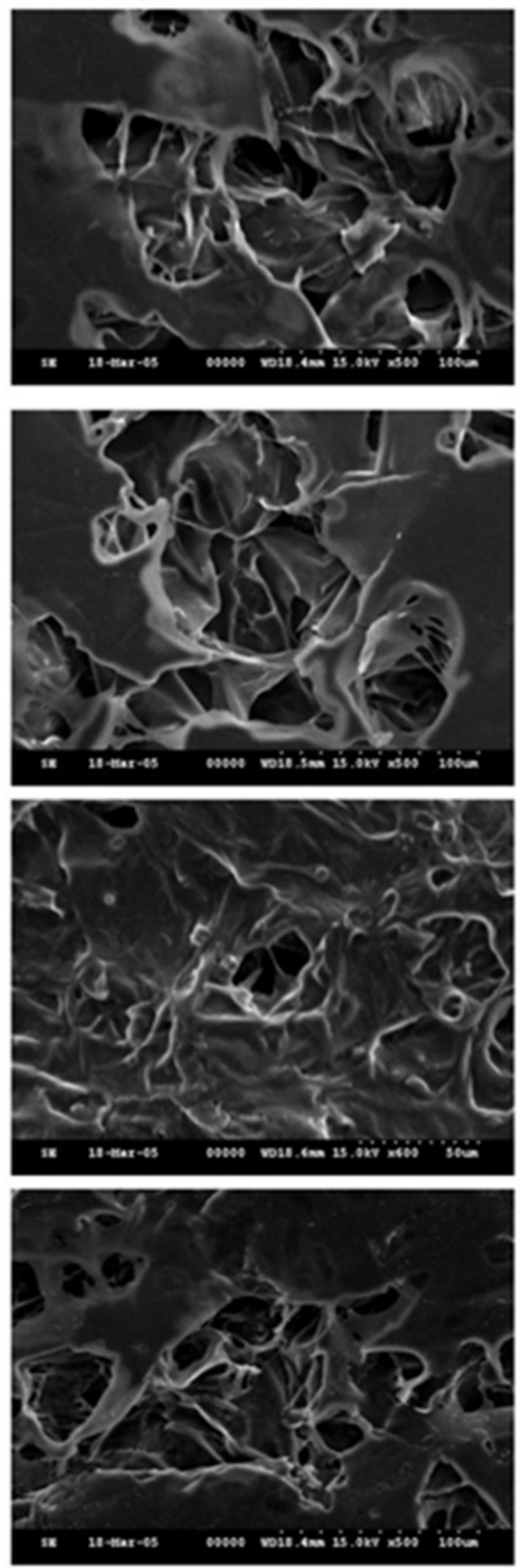


\section{Figure 3}

Attachment and proliferation of (A) Primary human epidermal keratinocyte (PHEK) and (B) primary human dermal fibroblasts (PHDF) (C) human adipose-derived stem cells (ASCs) grown on G/C/P and C/P biocomposites.

The blank wells (tissue culture polystyrene, TCP) served as the control. $*$ : indicates $P<0.05$ between TCP and other groups. 
A
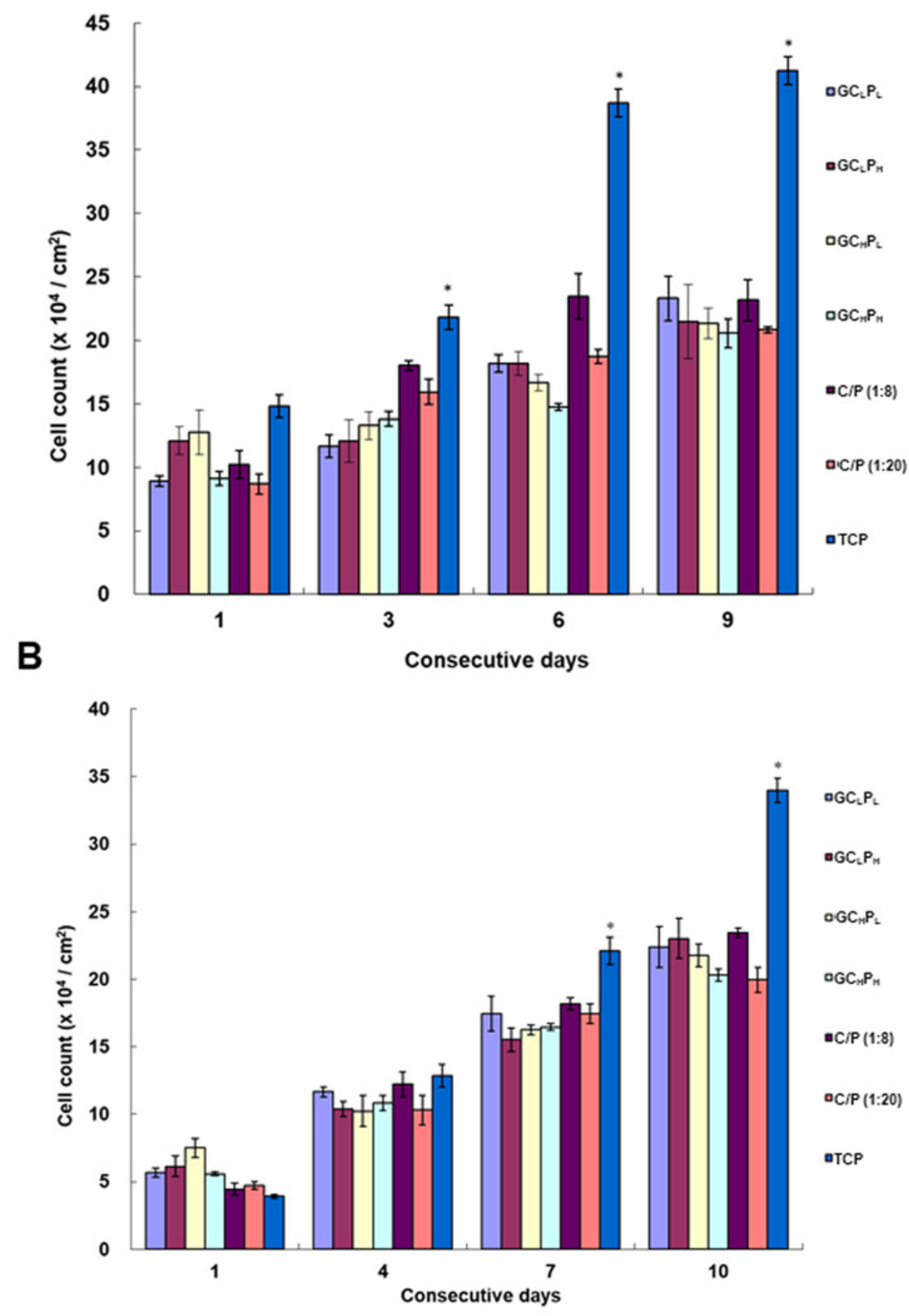

C

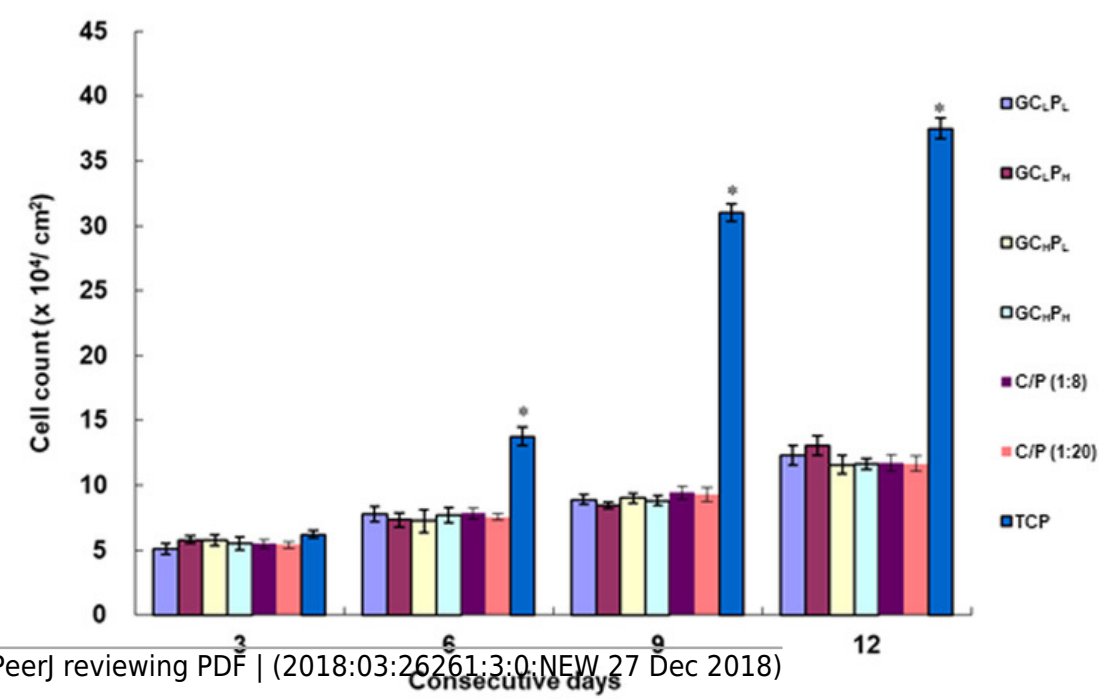




\section{Figure 4}

Immunohistochemical assay for (A) PHEK grown on four G/C/P biocomposites at 1, 3 days and for (B) PHDF grown on four biocomposites at 1, 3 days, as the staining controls lacking primary antibody were present

in the second set of columns (in the right side). CK-14 was a specific protein for PHEK, whereas alpha tubulin was a specific protein for PHDF. w/o: without. (scale bar: $250 \mu \mathrm{m}$ ) 
A

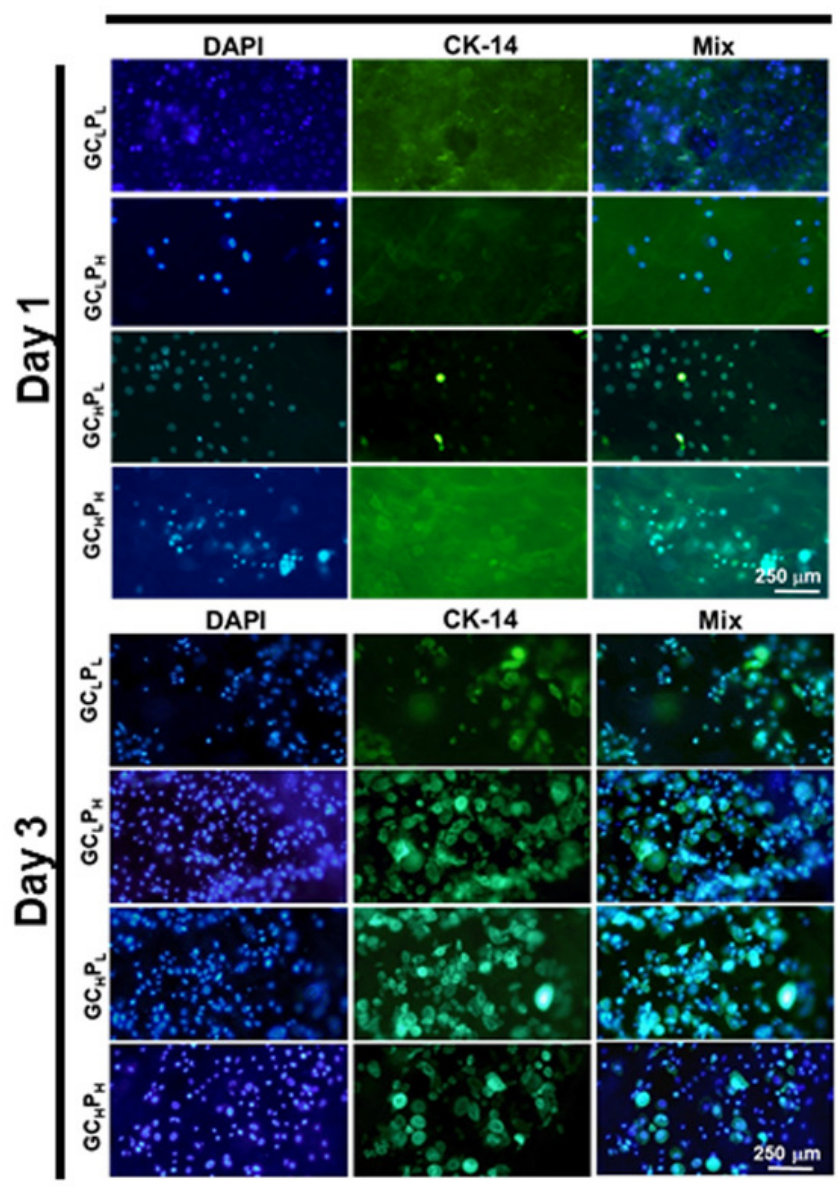

Control lacking primary antibody

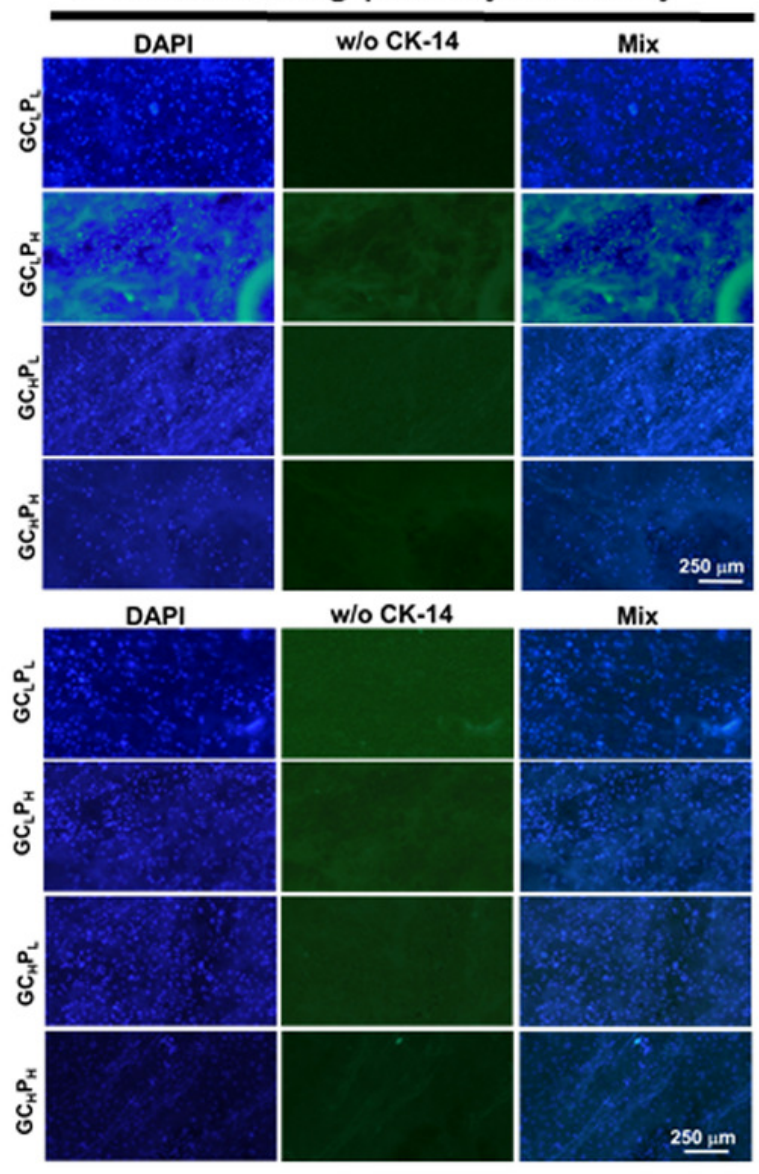

B
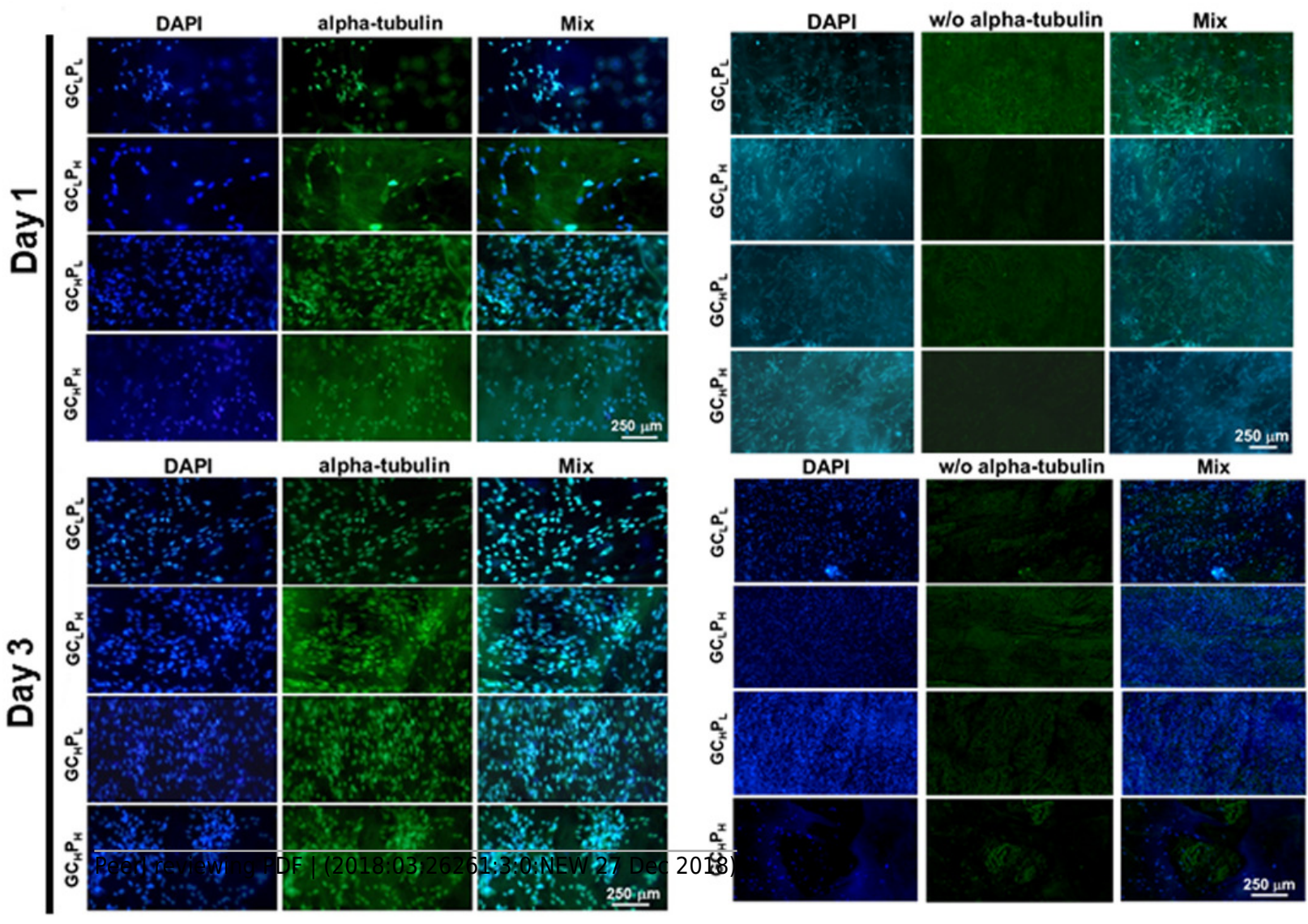


\section{Figure 5}

Comparison of wound closure: (A) the appearance and (B) the area of wound in the fullthickness skin defect of nude mice covered with $\mathrm{GC}_{\mathrm{L}} \mathrm{P}_{\mathrm{H}}$ scaffold and those seeded with ASCs until 21 days.

The untreated wounds were served as the control. $*$ : indicates $P<0.05$ between control and other groups. 
A
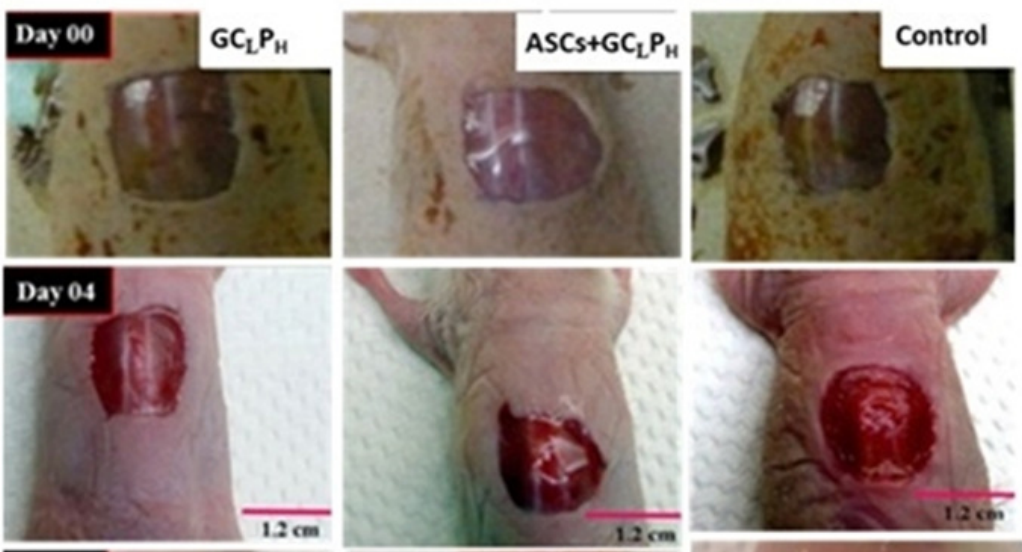

Day 08

$x^{4}$

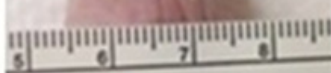
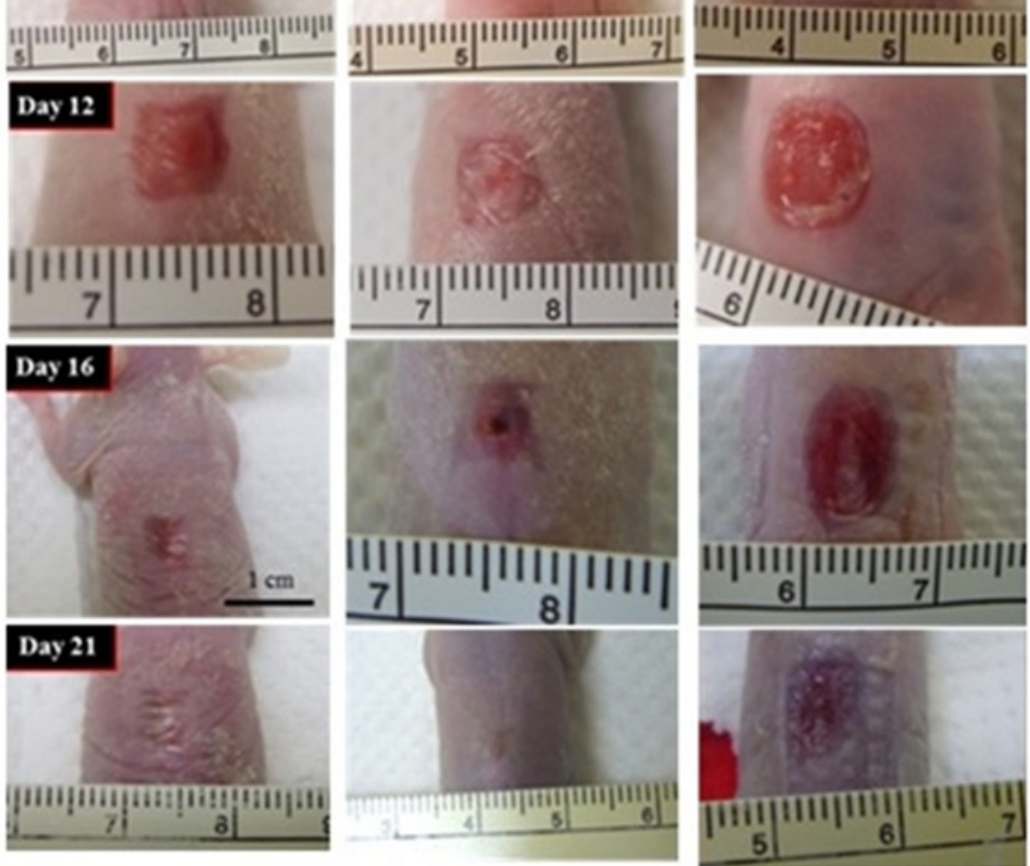

B

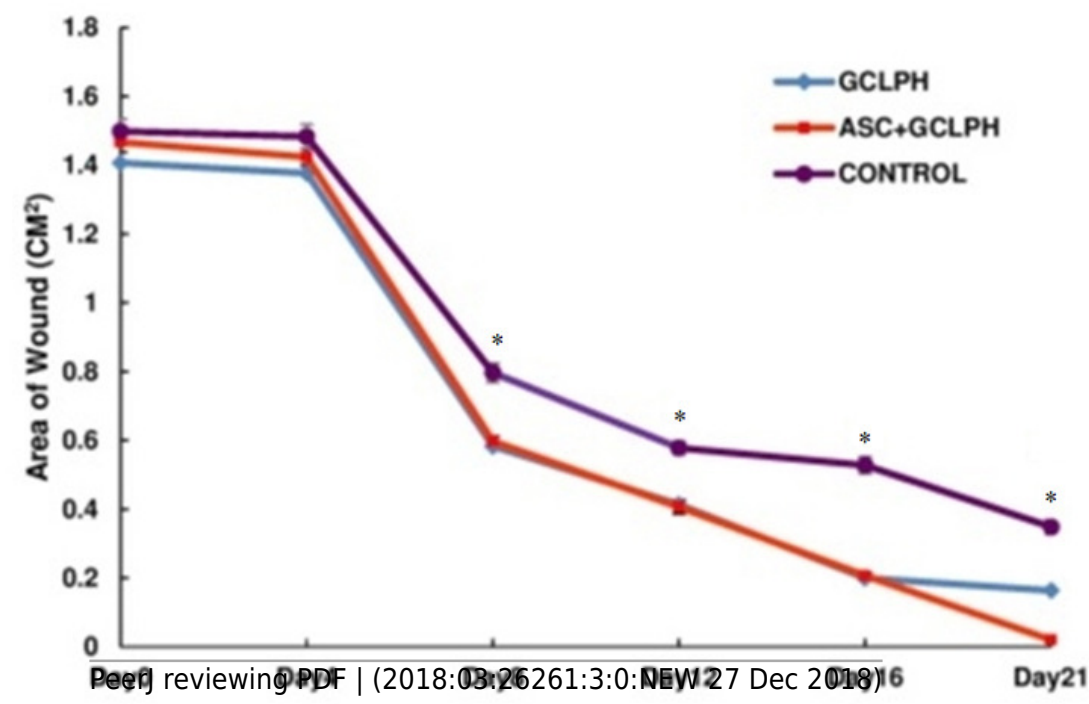




\section{Figure 6}

Collagen deposition in the wound bed by Gomori's trichrome staining for the histology of cultured skin model

Collagen deposition in the wound bed by Gomori's trichrome staining for the histology of cultured skin model in the groups of (A) open wound (B) $G C_{L} P_{H}$ only (C) ASCs-seeded $G C_{L} P_{H}$ ( $40 \mathrm{X}$; scale bar: $30 \mu \mathrm{m}$ ) on the full-thickness skin defect of nude mice for 14 days. The panels (D) to (F) were the magnified images of the box area (red rectangle) in (A) to (C) respectively (100x ; scale bar: $5 \mu \mathrm{m})$. Arrows indicate the positive cells. 
A

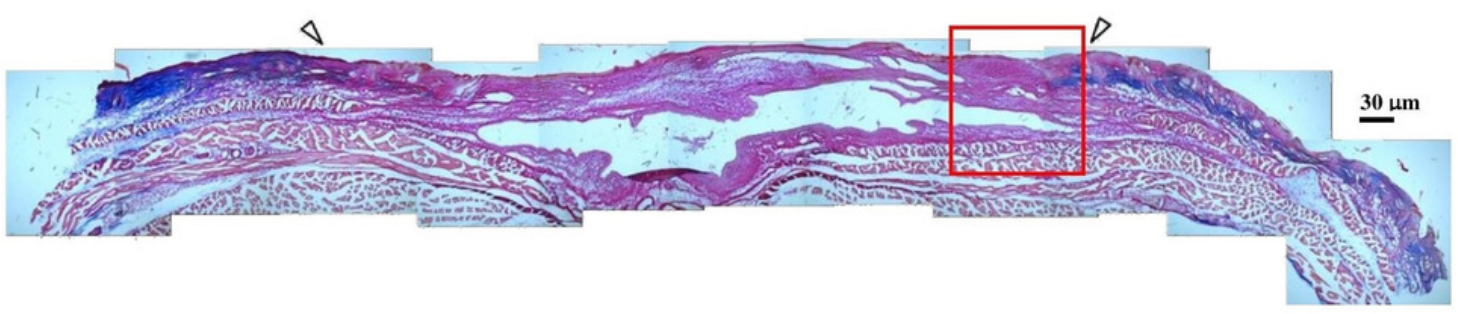

B

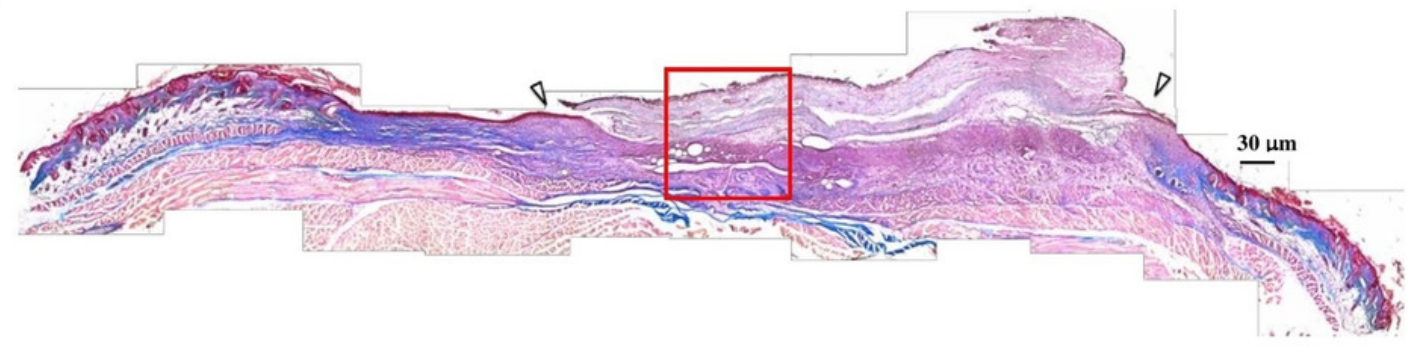

C

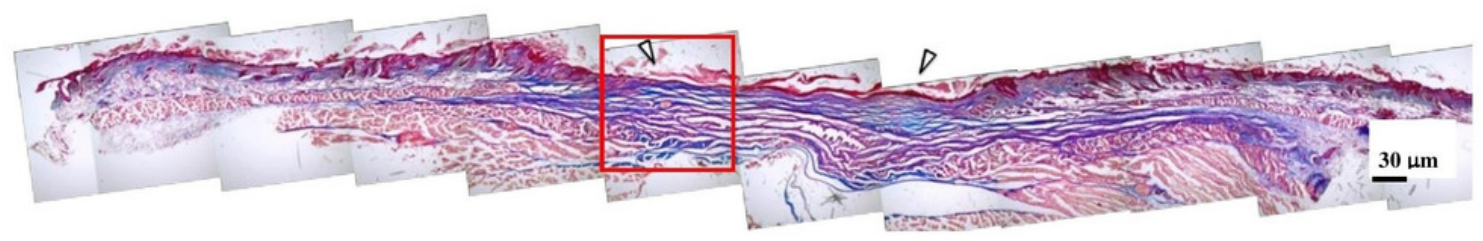

D

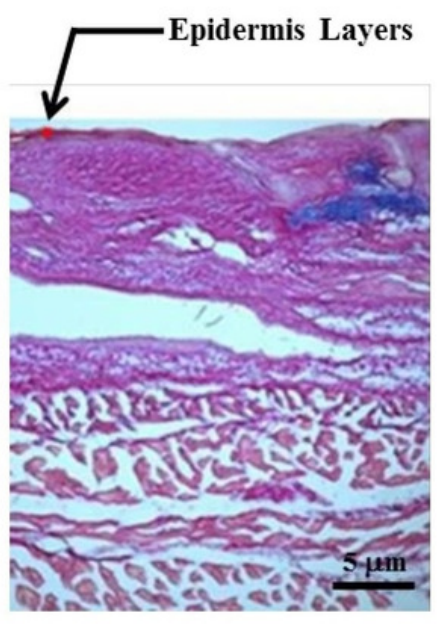

$\mathbf{F}$

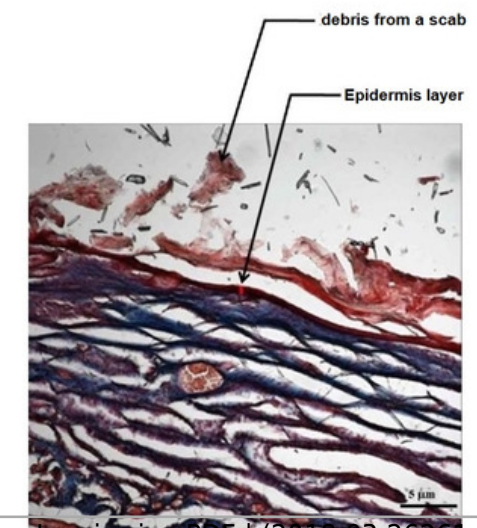

Peerreviewing pos $72018.03: 26261: 3: 0: N E W 27$ Dec 2018)
E

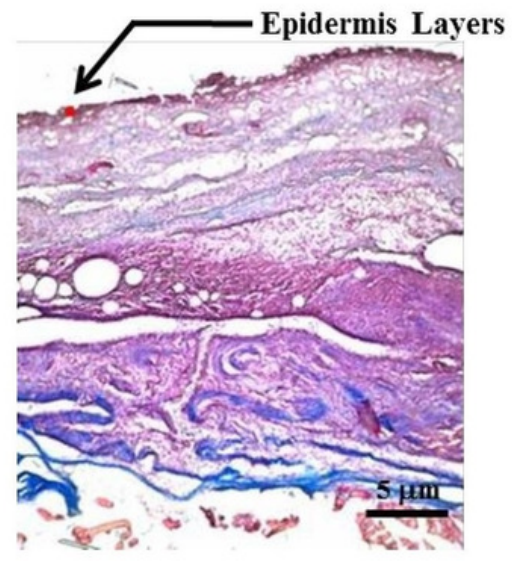




\section{Table $\mathbf{1}$ (on next page)}

The composition and preparation of four types of GCP biocomposites 
1 Table 1. The preparation parameters of GCP and C/P biocomposites

\begin{tabular}{llllcc}
\hline & $\begin{array}{l}\text { Gelatin/ddH } \\
(200 \mu \mathrm{O})\end{array}$ & $\begin{array}{l}\text { Collagen } / 1 \% \text { HAc } \\
(50 \mu \mathrm{l})\end{array}$ & $\begin{array}{l}\mathrm{PCL} / \mathrm{DCM} \\
(500 \mu \mathrm{l})\end{array}$ & $\begin{array}{c}\mathrm{C} / \mathrm{G}+\mathrm{C} \\
(\%, \mathrm{w} / \mathrm{w})\end{array}$ & $\begin{array}{c}\mathrm{G}+\mathrm{C}: \mathrm{P} \\
(\mathrm{w} / \mathrm{w})\end{array}$ \\
\hline $\mathrm{GC}_{\mathrm{L}} \mathrm{P}_{\mathrm{L}}$ & $2 \mathrm{mg} / \mathrm{ml}$ & $1.25 \mathrm{mg} / \mathrm{ml}$ & $7.4 \mathrm{mg} / \mathrm{ml}$ & 14 & $1: 8$ \\
$\mathrm{GC}_{\mathrm{L}} \mathrm{P}_{\mathrm{H}}$ & $2 \mathrm{mg} / \mathrm{ml}$ & $1.25 \mathrm{mg} / \mathrm{ml}$ & $18.5 \mathrm{mg} / \mathrm{ml}$ & 14 & $1: 20$ \\
$\mathrm{GC}_{\mathrm{H}} \mathrm{P}_{\mathrm{L}}$ & $0.8 \mathrm{mg} / \mathrm{ml}$ & $6.05 \mathrm{mg} / \mathrm{ml}$ & $7.4 \mathrm{mg} / \mathrm{ml}$ & 35 & $1: 8$ \\
& & & & & \\
$\mathrm{GC}_{\mathrm{H}} \mathrm{P}_{\mathrm{H}}$ & $0.8 \mathrm{mg} / \mathrm{ml}$ & $6.05 \mathrm{mg} / \mathrm{ml}$ & $18.5 \mathrm{mg} / \mathrm{ml}$ & 35 & $1: 20$ \\
& & & & & $1: 8$ \\
$\mathrm{C} / \mathrm{P}(1: 8)$ & & $1.85 \mathrm{mg} / \mathrm{ml}(250 \mu \mathrm{l})$ & $7.4 \mathrm{mg} / \mathrm{ml}$ & & \\
$\mathrm{C} / \mathrm{P}(1: 20)$ & & $1.85 \mathrm{mg} / \mathrm{ml}(250 \mu \mathrm{l})$ & $18.5 \mathrm{mg} / \mathrm{ml}$ & & $1: 20$
\end{tabular}

2 G: gelatin, $C_{L}$ : collagen with lower proportion, $C_{H}$ : collagen with higher proportion, $P_{L}$ : 3 PCL with lower proportion, $\mathbf{P}_{\mathbf{H}}$ : PCL with higher proportion 
Table 2 (on next page)

Cumulative protein release from $\mathrm{G} / \mathrm{C} / \mathrm{P}$ biocomposites in $\mathrm{PBS}$ at $37^{\circ} \mathrm{C}$. 
1 Table 2. Cumulative protein release from $\mathrm{G} / \mathrm{C} / \mathrm{P}$ biocomposites in $\mathrm{PBS}$ at $37^{\circ} \mathrm{C}$.

$\begin{array}{lllllllll}\text { Gelatin Collagen PCL } & 6 \mathrm{~h} & 12 \mathrm{~h} & 24 \mathrm{~h} & 72 \mathrm{~h} & 144 \mathrm{~h} & 216 \mathrm{~h} & 288 \mathrm{~h}\end{array}$

\begin{tabular}{llllccccccc} 
& $(\%)$ & $(\%)$ & $(\%)$ & $(\%)$ & $(\%)$ & $(\%)$ & $(\%)$ & $(\%)$ & $(\%)$ & $(\%)$ \\
\hline $\mathrm{GC}_{\mathrm{L}} \mathrm{P}_{\mathrm{L}}$ & 9.61 & 1.50 & 88.89 & $78 \pm 2$ & $96 \pm 3$ & $100 \pm 4$ & $107 \pm 4$ & $107 \pm 4$ & $107 \pm 4$ & $108 \pm 4$ \\
$\mathrm{GC}_{\mathrm{L}} \mathrm{P}_{\mathrm{H}}$ & 4.12 & 0.64 & 95.24 & $52 \pm 2$ & $73 \pm 1$ & $76 \pm 1$ & $82 \pm 3$ & $82 \pm 3$ & $82 \pm 3$ & $83 \pm 3$ \\
$\mathrm{GC}_{\mathrm{H}} \mathrm{P}_{\mathrm{L}}$ & 7.99 & 3.12 & 88.89 & $52 \pm 1$ & $59 \pm 2$ & $62 \pm 2$ & $64 \pm 2$ & $66 \pm 3$ & $67 \pm 4$ & $71 \pm 5$ \\
$\mathrm{GC}_{\mathrm{H}} \mathrm{P}_{\mathrm{H}}$ & 3.42 & 1.34 & 95.24 & $62 \pm 15$ & $78 \pm 16$ & $81 \pm 15$ & $85 \pm 15$ & $86 \pm 15$ & $92 \pm 18$ & $94 \pm 17$
\end{tabular}

2 G: gelatin, $C_{L}$ : collagen with lower proportion, $C_{H}$ : collagen with higher proportion, $P_{L}$ :

3 PCL with lower proportion, $\mathbf{P}_{\mathrm{H}}$ : PCL with higher proportion, h: hours (time) 


\section{Table 3(on next page)}

The analysis of $G / C / P$ biocomposites for the mean pore size $(n=6)$ and thermal characteristics $(n=3$, values are expressed as mean \pm SD). 
1 Table 3. The analysis of $\mathrm{G} / \mathrm{C} / \mathrm{P}$ biocomposites for thermal characteristics ( $\mathrm{n}=3$, values are 2 expressed as mean $\pm \mathrm{SD}$ ).

\begin{tabular}{llll}
\hline & $\mathrm{Tm}\left({ }^{\circ} \mathrm{C}\right)$ & $\begin{array}{l}\text { Crystallinity } \\
(\%)\end{array}$ & Reference \\
\hline $\mathrm{GC}_{\mathrm{L}} \mathrm{P}_{\mathrm{L}}$ & $59.2 \pm 1.5$ & $53.9 \pm 1.8$ & \\
$\mathrm{GC}_{\mathrm{L}} \mathrm{P}_{\mathrm{H}}$ & $61.5 \pm 2.0$ & $54.8 \pm 2.4$ & \\
$\mathrm{GC}_{\mathrm{H}} \mathrm{P}_{\mathrm{L}}$ & $58.3 \pm 0.2$ & $55.1 \pm 1.2$ & \\
$\mathrm{GC}_{\mathrm{H}} \mathrm{P}_{\mathrm{H}}$ & $59.8 \pm 0.3$ & $57.1 \pm 1.4$ & \\
$\mathrm{PCL}(100 \%)$ film & $62.8 \pm 0.2$ & $54.2 \pm 5.4$ & Dai et al., 2004 \\
$\mathrm{C} / \mathrm{P}(1: 8)$ & $60.7 \pm 0.2$ & $48.5 \pm 4.4$ & Dai et al., 2004 \\
$\mathrm{C} / \mathrm{P}(1: 20)$ & $63.7 \pm 0.4$ & $63.5 \pm 3.8$ & Dai et al., 2004 \\
\hline
\end{tabular}




\section{Table 4 (on next page)}

The tensile properties of four GCP and C/P biocomposites ( $n=3$; values are expressed as mean $\pm S D$ ). 
1 Table 4. The tensile properties of four $\mathrm{GCP}$ and $\mathrm{C} / \mathrm{P}$ biocomposites $(\mathrm{n}=3$; values are 2 expressed as mean $\pm \mathrm{SD}$ ).

\begin{tabular}{llll}
\hline & $\begin{array}{l}\text { Young's modulus } \\
(\mathrm{MPa})\end{array}$ & $\begin{array}{l}\text { Elongation } \\
(\%)\end{array}$ & $\begin{array}{l}\text { Tensile strength } \\
(\mathrm{MPa})\end{array}$ \\
\hline $\mathrm{GC}_{\mathrm{L}} \mathrm{P}_{\mathrm{H}}$ & $35.5 \pm 8.3$ & $10.7+1.8$ & $2.5 \pm 1$ \\
$\mathrm{GC}_{\mathrm{H}} \mathrm{P}_{\mathrm{H}}$ & $46.6 \pm 6.2$ & $6.7 \pm 1.7$ & $2.2 \pm 0.4$ \\
$\mathrm{GC}_{\mathrm{L}} \mathrm{P}_{\mathrm{L}}$ & $30.8 \pm 9.1$ & $5.1 \pm 1.5$ & $0.8 \pm 0.1$ \\
$\mathrm{GC}_{\mathrm{H}} \mathrm{P}_{\mathrm{L}}$ & $59.5 \pm 8.3$ & $7.4 \pm 1.8$ & $2.2 \pm 0.5$ \\
$\mathrm{C} / \mathrm{P}(1: 20)$ & $75.8 \pm 4.2$ & $9.4+1.3$ & $3.7+0.4$ \\
$\mathrm{C} / \mathrm{P}(1: 8)$ & $5.7+3.8$ & $18.1+6.1$ & $0.5 \pm 0.1$ \\
\hline
\end{tabular}

